\title{
Transport and degradation of phytoplankton in permeable sediment
}

\author{
Markus Huettel ${ }^{1}$ and Antje Rusch \\ Max-Planck-Institute for Marine Microbiology, Celsiusstr. 1, 28359 Bremen, Germany
}

\begin{abstract}
In flume and field experiments we demonstrate that interfacial water flows, generated when bottom currents interact with sea bed topography, provide a fast and efficient pathway for the transport of suspended phytoplankton into subsurface layers of permeable sandy sediments. The advective transport, associated with small mounds and ripples as commonly found on shelf sediments, increased penetration depth of unicellular algae (Dunaliella spec.) into sandy sediment (permeability $k=4 \times 10^{-11} \mathrm{~m}^{2}$ ) up to a factor of 7 and flux up to a factor of 9 relative to a smooth control sediment. The pore water flow field produced a distinct distribution pattern of particulate organic matter in the sediment with subsurface concentration maxima and zones depleted of algae. Flux chamber simulations of advective transport of algae into sands of different grain sizes revealed increasing fluxes, algal penetration depths, and degradation rates with increasing permeability of the sediment. Two experiments conducted in intertidal sand flats confirmed the importance of the advective interfacial transport of phytoplankton for natural settings, showing permeability-dependent penetration of planktonic algae into embedded sand cores of different grain sizes. The significance of our results is discussed with respect to particulate organic matter flux and mineralization in shelf sands, and we suggest the concept of a decomposition layer.
\end{abstract}

In contrast to muddy sea beds with low permeabilities, where transport of solutes is mainly driven by diffusion, water can flow through marine sands, providing a fast carrier for the exchange of substances between the water column and the upper sediment layers. Surface gravity waves cause pressure oscillations that increase fluid exchange at the sediment-water interface and dispersion of solutes within the bed (Webb and Theodor 1968; Riedl et al. 1972; Harrison et al. 1983). Bottom currents deflected by sediment topography create small horizontal pressure gradients that force water into the bed upstream and downstream of protruding surface structures and draw pore water to the sediment surface where the pressure is lowest (Fig. 1) (Savant et al. 1987; Thibodeaux and Boyle 1987; Huettel and Gust 1992a). Huettel et al. (1996) showed that the interfacial water flows can carry particulate tracers several centimeters into sands. Shells of sea scallops on sandy sediment increase the deposition of diatoms (Pilditch et al. 1998).

Permeable sands are most common in coastal environments (Riggs et al. 1996), and relict sands cover approximately $70 \%$ of the continental shelves (Emery 1968). In these nearshore waters, high nutrient concentrations boost phytoplankton growth to generate about $30 \%$ of the total oceanic primary production in a zone covering less than $10 \%$ of the world's ocean area (Walsh 1988; Wollast 1991).

Up to $50 \%$ of the organic matter produced in the water column on the shelf is decomposed at the seafloor (Rowe et al. 1988; Wollast 1991; Bacon et al. 1994). Wind, waves, and tidal currents cause deep mixing of the water column, carrying phytoplankton cells to the bottom (Jones et al. 1998). Velocity and turbulence of bottom currents in the

\footnotetext{
${ }^{1}$ Corresponding author (mhuettel@mpi-bremen.de).

Acknowledgments

We thank Susanne Menger and Martina Alisch for assistance with the experimental setups, sampling, phytoplankton counting, and chlorophyll analyses. The comments of two anonymous reviewers helped to improve the manuscript.
}

shallow water, however, exceed the settling velocity of the organic material by far counteracting deposition (Jago and Jones 1998). Relatively high shear forces in the turbulent boundary layer break down aggregates of organic matter, decreasing their size and sinking rate (Eisma and Kalf 1987; Milligan and Hill 1998). Nonetheless, tight coupling of water column and sedimentary chlorophyll indicate a rapid transfer mechanism for the incorporation of these particles into the shelf bed (Hansen and Blackburn 1992; Burford et al. 1994; Buscail et al. 1995).

Filter feeding and bioturbation of benthic invertebrates enhance benthic-pelagic coupling (Rhoads 1973; Aller 1978; Graf 1992), but abundances of bottom dwellers decrease in frequently resuspended sandy shelf beds (Emerson 1990; Ong and Krishnan 1995; McLachlan 1996). Jenness and Duineveld (1985) suggest that in such environments, moving ripples enhance burial of material; however, this process requires that organic material could settle on the sediment surface during phases of reduced bottom currents.

The purpose of this study was to assess whether interfacial water flows, caused by boundary flow-topography interaction, increase transport and degradation of suspended phytoplankton in sands with permeabilties similar to those found in shallow shelf sediments. We conducted flume experiments to investigate the process of the interfacial algal cell transport and two in situ experiments to demonstrate the effects of this process in the natural environment. A novel chamber technique was used to investigate flux and degradation of Dunaliella cells in sediments of different permeabilities. Based on our findings and data from the literature, we suggest a concept of organic matter degradation for sediments of different water depths.

\section{Methods}

Four flume experiments-Four flume experiments were designed to assess (1) the intrusion of algal cells into a smooth permeable sediment core (FLU-S), (2) the impact of 


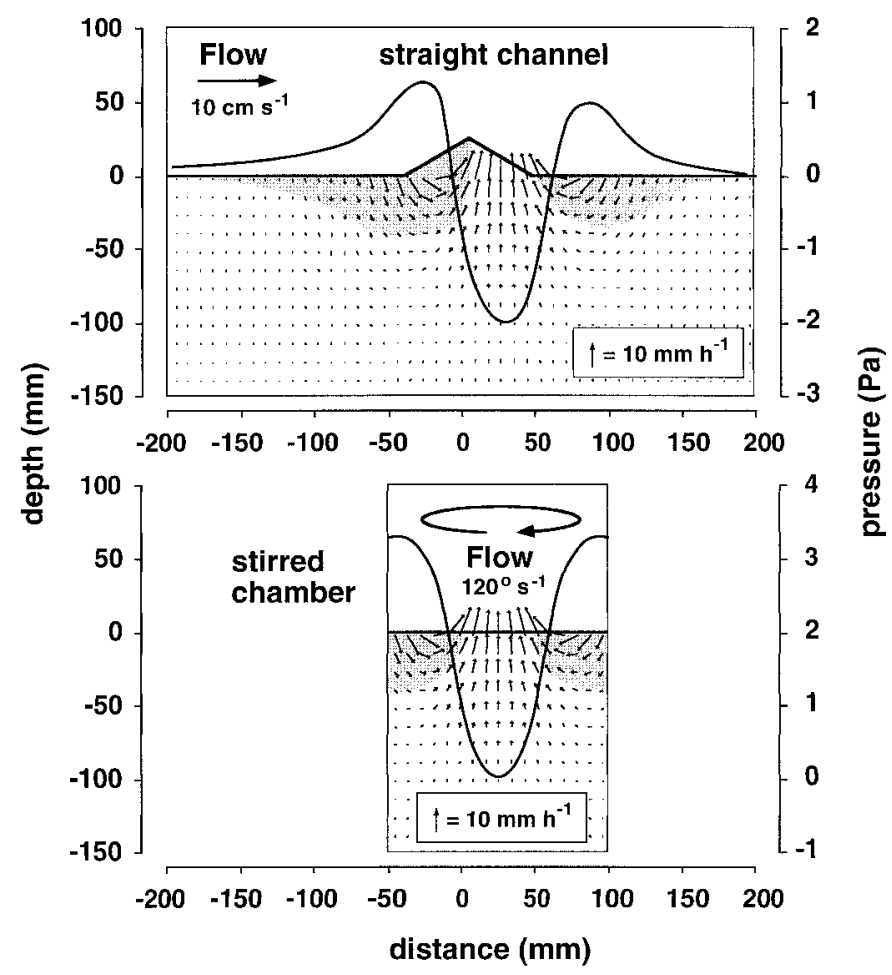

Fig. 1. Schematic of the advective pore water flow field under sediment topography exposed to unidirectional flow in a straight open channel and in sediment exposed to a rotating water column in a stirred chamber. The solid curved line depicts the pressure distribution at the sediment-water interface. Shaded areas mark the intrusion zones of water, and the arrows in the sediments show direction and magnitude of the advective pore water flows.

small mounds on the flux of algae from the boundary layer into the sediment (FLU-M1, FLU-M2), and (3) the effect of a sediment ripple on intrusion and distribution of algae cells within the sediment (FLU-R).

The recirculating flume had an open channel section of $200-\mathrm{cm}$ length, 35-cm width, and $12-\mathrm{cm}$ height. The sediment core was placed in a drop box $(60-\mathrm{cm}$ long, $35-\mathrm{cm}$ wide, $20-\mathrm{cm}$ deep) located $90-\mathrm{cm}$ downstream from the channel entrance. The sediment consisted of medium marine quartz sand (Table 1) depleted of any macrofauna and algae. Prior to the experiments, the sediment was compacted by applying low-frequency vibrations, and the surface was carefully smoothed. Except for the control experiment (FLU-S), topography then was built on the surface using the same sand. In FLU-M1 and FLU-M2, 10 small mounds (60-mm base diameter, $20-\mathrm{mm}$ height) were built on the sediment surface, arranged to maximize the distance between the mounds and to minimize flow obstruction for each other (Fig. 2). In FLU-R the topography consisted of a sediment ripple (110-mm width, 30-mm height) built perpendicular to the flow across the center of the sediment core.

The flume was filled with 160 liters of filtered artificial sea water (salinity 35 ), to a water depth of $10 \mathrm{~cm}$. A large propeller (17-cm diameter) located in the return circuit of the flume generated flow without damaging suspended algae. The flow velocity in the open channel was adjusted to 10
Table 1. The characteristics of the sands used for the flume and field experiments. Permeabilities were measured with a standard constant head permeameter.

\begin{tabular}{|c|c|c|c|c|}
\hline $\begin{array}{c}\text { Flume } \\
\text { experiments }\end{array}$ & $\begin{array}{c}\text { Median } \\
(\mu \mathrm{m})\end{array}$ & $\begin{array}{l}\text { Sorting } \\
\text { P75/P25 }\end{array}$ & $\begin{array}{l}\text { Permeability } \\
\left(\times 10^{-12} \mathrm{~m}^{2}\right)\end{array}$ & $\begin{array}{l}\text { Porosity } \\
\text { (\% vol) }\end{array}$ \\
\hline \multicolumn{5}{|c|}{ FLU-S, FLU-R, FLU-M1, FLU-M2 } \\
\hline All cores & 350 & 1.5 & 40.5 & 32 \\
\hline \multicolumn{5}{|c|}{ Chamber experiments } \\
\hline \multicolumn{5}{|c|}{ CHA-1 } \\
\hline Core 1 & 187 & 1.4 & 7.1 & 20.8 \\
\hline Core 2 & 187 & 1.4 & 7.0 & 21.0 \\
\hline Core 3 & 375 & 1.4 & 28.5 & 20.2 \\
\hline Core 4 & 375 & 1.4 & 30.5 & 20.0 \\
\hline Core 5 & 750 & 1.4 & 113.9 & 20.1 \\
\hline Core 6 & 1,500 & 1.4 & 455.4 & 20.4 \\
\hline \multicolumn{5}{|l|}{ CHA-2 } \\
\hline Core 1 & 105 & 2.4 & 0.2 & 47.2 \\
\hline Core 2 & 150 & 1.9 & 4.6 & 35.6 \\
\hline Core 3 & 600 & 2.3 & 72.3 & 32.1 \\
\hline Core 4 & 1,050 & 3.2 & 223.1 & 32.2 \\
\hline \multicolumn{5}{|c|}{ Field experiments } \\
\hline \multicolumn{5}{|c|}{ FLD-1 } \\
\hline Core 1 & 200 & 1.6 & 11 & 20.8 \\
\hline Core 2 & 500 & 1.7 & 67 & 20.5 \\
\hline Core 3 & 1,150 & 1.9 & 346 & 20.0 \\
\hline Core 4 & 2,000 & 1.7 & 1,027 & 20.4 \\
\hline Core 5 & 200 & 1.6 & 11 & 20.5 \\
\hline Core 6 & 500 & 1.7 & 70 & 21.5 \\
\hline Core 7 & 1,150 & 1.9 & 350 & 20.5 \\
\hline Core 8 & 2,000 & 1.7 & 1,015 & 20.0 \\
\hline \multicolumn{5}{|l|}{ FLD-2 } \\
\hline Core 1 & 187 & 1.4 & 18 & 20.8 \\
\hline Core 2 & 750 & 1.4 & 126 & 20.4 \\
\hline
\end{tabular}

$\mathrm{cm} \mathrm{s}^{-1}$ using a Mini Water ${ }^{\boxplus l}$ flow sensor mounted $8 \mathrm{~cm}$ above the sediment surface at the downstream end of the core (shear velocity $0.33 \mathrm{~cm} \mathrm{~s}^{-1}$, shear stress $0.11 \mathrm{~g} \mathrm{~cm}^{-1} \mathrm{~s}^{-1}$ ). The turbulent boundary layer (boundary layer Reynolds number $\operatorname{Re}_{b}=3,400$ ) above the smooth control core had a thickness, $z_{b}$, of $\geq 3.8 \mathrm{~cm}$. A thin opaque PVC sheet that covered the flume prevented algal growth and evaporation, and a cooling unit kept the water temperature at $20 \pm 0.1^{\circ} \mathrm{C}$. Oxygen concentration in the flume remained $>95 \%$ air saturation at all times. Before addition of algae in FLU-S and FLU-M2, we measured oxygen concentration profiles in the sediment with Clark-type microelectrodes as described by Revsbech (1989).

Suspensions of the planktonic unicellular algae Dunaliella spec. ( $8 \pm 6 \mu \mathrm{m}$ diameter, Chlorophyceae) were added to the flume at the beginning of each experiment to produce initial chlorophyll $a(\mathrm{Chl} a)$ concentrations in the recirculating water of $68,103,161$, and $74 \mu \mathrm{g} \mathrm{L}^{-1}$ for FLU-S, FLUM1, FLU-M2, and FLU-R, respectively. After 3 (FLU-S, FLU-R, FLU-M2), and 5 (FLU-M1) days, the flume water was drained and sediment subcores (26-mm diameter, 180mm length) were taken at the locations depicted in Fig. 2; in the smooth control core (FLU-S), 12 subcores were sampled from random locations. The subcores were sliced in 


\section{FLU-M1, FLU-M2}

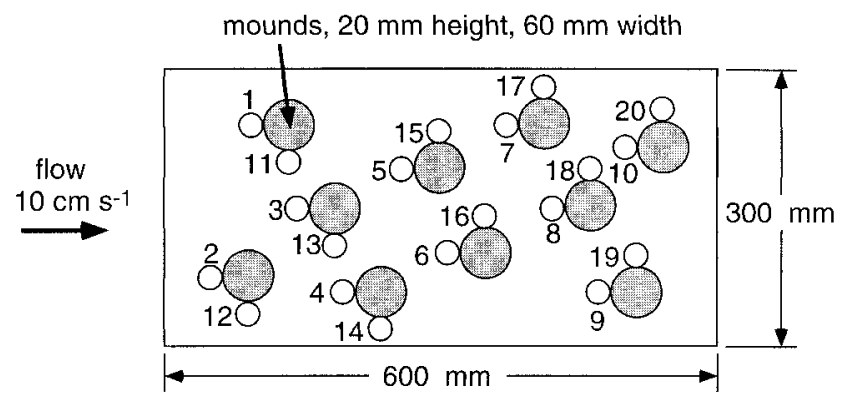

\section{FLU-R}

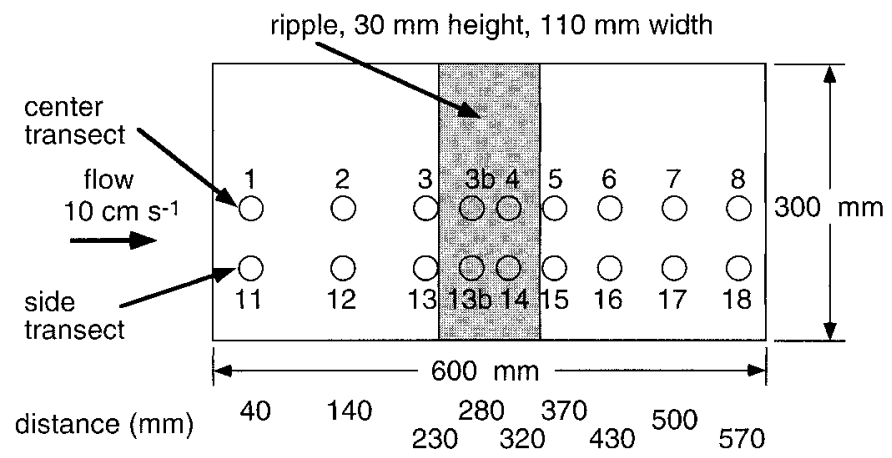

Fig. 2. Top view of the sediment cores in the flume experiments. The upper panel shows the positions of the mounds (large shaded circles) and the locations of the sediment subcores taken after the experiments (small open circles). The lower panel depicts the positions of the ripple and the sediment subcores taken after the experiment.

5-mm (FLU-S), or 10-mm (FLU-M1, FLU-M2) intervals down to $60-\mathrm{mm}$ depth; in FLU-R, the subcores were analyzed down to $70-\mathrm{mm}$ depth (5-mm and 10-mm intervals). Algal cells and sand grains were separated by resuspending the individual sediment slices four times in $50 \mathrm{ml}$ of filtered seawater and filtering the supernatant after $20 \mathrm{~s}$ deposition time. In the ripple experiment (FLU-R), the supernatant was drawn on black polycarbonate membranes (Nuclepore, 0.2$\mu \mathrm{m}$ pores) and Dunaliella cells were counted under a Zeiss Axiophot epifluorescence microscope (excitation wave length 450-490 nm, magnified 160 times). In all other flume experiments, Chl $a$ concentrations were used to quantify the concentration of algae. Here, the supernatant was filtered through GF-F filters (Whatman, $2.2 \mu \mathrm{m}$ ), and subsequent rinsing with filtered seawater assured that only Chl $a$ contained in algal cells was measured. The Chl $a$ content of the filters was analyzed spectrophotometrically according to Rowan (1989).

Two chamber experiments-In two chamber experiments we investigated (1) the penetration of algal cells into sieved sands of selected grain sizes (CHA-1), (2) the penetration of algae into natural sediments of different permeabilities (CHA-2), and (3) the degradation of algal cells in the sieved and natural sediments (CHA-1, CHA-2).
In a centrally stirred chamber, a pore water flow field can be generated in the incubated sediment core that is similar to that produced by bottom currents interacting with sediment topography (Fig. 1). The rotating water column over the smooth sediment core creates a radial pressure field with lowest pressure at the center of the sediment surface and highest pressure at the outer rim (Huettel and Gust 1992b). The pressure distribution along the diameter of the incubated sediment compares to that along the cross section of a sediment ripple (perpendicular to crest) exposed to two-dimensional flow (Huettel and Gust 1992a). By selecting the appropriate diameter and stirring speed, the chamber can be used to mimic the pressure gradients at a ripple of common size. In permeable sands, the radial pressure gradient in the chamber forces water into the sediment at the outer rim of the incubated core. The water flows on a curved path through the sediment toward the center of the sediment surface, where the pore water emerges (Huettel and Gust 1992b). Tracer experiments and calculation of the vorticity vectors show that the rotational movement of the water column is not transferred to the pore water (Khalili et al. 1997). For further details of flow and pressure fields in cylindrical chambers we refer to Basu and Khalili (1999) and Glud et al. $(1995,1996)$.

We combined six (CHA-1) and four (CHA-2) cylindrical chambers $(19 \mathrm{~cm}$ inner diameter, $28 \mathrm{~cm}$ inner height, 8 -liter volume) for sediment incubations (Table 1). One additional chamber was divided horizontally by a false bottom with two pressure ports (one in the center, one $8.5 \mathrm{~cm}$ away from the center) into an upper compartment containing the water and a lower compartment housing a differential pressure gauge (Effa GA 63) connected via stiff tubing to the ports. The water in all chambers ( 2.5 liters each) was stirred by flat disks (17-cm diameter) rotating $7 \mathrm{~cm}$ above the sediment cores $\left(5 \mathrm{dm}^{3}\right.$ each). All axes of the stirring disks were connected via toothed belts to a DC servo-motor and rotated at exactly the same constant angular velocity. The motor was controlled by a computer that used the signal of the pressure gauge to adjust the rotation of the stirring disks to the selected pressure differential $\left(0.1 \mathrm{~Pa} \mathrm{~cm}^{-1}\right)$ that equaled the differential previously measured at a ripple exposed to twodimensional flow (Huettel et al. 1996). All chambers were kept in a temperature bath $\left(20^{\circ} \mathrm{C}\right)$ and covered by an opaque sheet excluding all light.

In CHA-1, we incubated four different sieved sands of selected grain sizes, with grain size medians ranging from 187 to $1,500 \mu \mathrm{m}$ (Table 1 ), and the control chamber with false bottom simulated an impermeable sediment core. After insertion of the water-saturated sand cores, filtered seawater $(S=35)$ with Dunaliella was carefully added to each chamber, which produced an initial Chl $a$ concentration of 100 $\mu \mathrm{g} \mathrm{L}^{-1}$. A plastic sheet covering the sediment prevented mixing of algal cells into the sands during the filling procedure. After $72 \mathrm{~h}$, the overlying water in each chamber was drained and analyzed for Chl $a$ content. In addition, seven sediment subcores (20-mm diameter, 100-mm length) were taken across each chamber. These cores were sliced (5- and $10-\mathrm{mm}$ intervals), and sediment slices of the same depth layer were pooled to average $\mathrm{Chl} a$ concentrations over the core diameter. Dunaliella cells were extracted from each 
FLU-M2

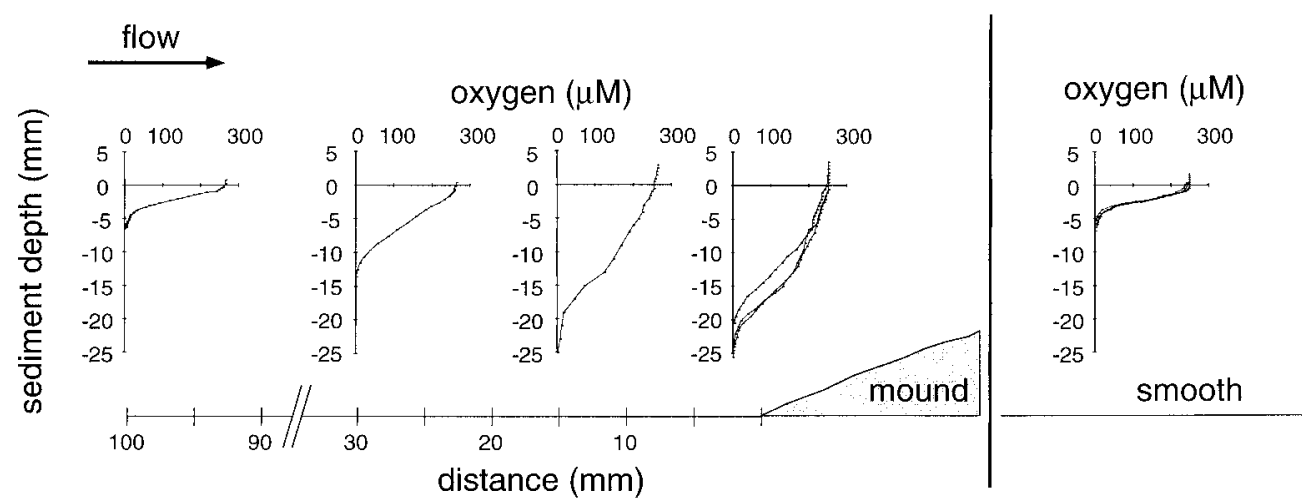

Fig. 3. Oxygen penetration depths measured with microelectrodes in the second mound experiment (FLU-M2) and the in the smooth surface experiment (FLU-S). depth layer as described for FLU-S. Extraction efficiencies were assessed by adding Dunaliella suspension of known concentration to 250-ml bottles containing the different sands and subsequent extraction, yielding $80 \pm 6 \%$ for 175 $\mu \mathrm{m}$ sand, $83 \pm 5 \%$ for $375-\mu \mathrm{m}$ sand, $86 \pm 6 \%$ for $750-\mu \mathrm{m}$ sand, and $86 \pm 6 \%$ for the $1,500-\mu \mathrm{m}$ sand.

In CHA-2, four natural sand cores with different grain sizes (Table 1) were placed in the chambers. These cores that originated from the German Bight (North Sea, $54^{\circ} 8^{\prime} \mathrm{N}$; $7^{\circ} 32^{\prime} \mathrm{E}$ ) were mixed and kept in a dark cold room for 7 months prior to the experiment to allow decomposition of algal material and chlorophyll. The initial Chl $a$ concentration in the chamber water after addition of Dunaliella was $540 \mu \mathrm{g} \mathrm{L}^{-1}$. After $144 \mathrm{~h}$, the entire sediment cores were sliced (1-, 2-, 5-, and 10-mm intervals), and the algal cells were extracted from each slice and analyzed for Chl $a$ as described for FLU-S.

Two field experiments-Two field experiments were conducted to investigate algal transport into sediment under field conditions.

The experiments were performed in intertidal sand flats at the German North Sea coast that combined accessibility and natural current and wave conditions. The first field experiment (FLD-1) was carried out in a sand flat close to Sahlenburg $\left(53^{\circ} 9^{\prime} \mathrm{N} ; 8^{\circ} 6^{\prime} \mathrm{E}\right)$, mean tidal range in this area is 1.2 $\mathrm{m}$. Two sets of four different sand cores (280-mm diameter, 300-mm height, grain sizes in Table 1) that were saturated with filtered seawater were inserted into the sediment approximately $100-\mathrm{m}$ seaward from the mean high-tide line. During the following high tide, $3 \times 500 \mathrm{ml}$ water samples were collected and preserved ( $2 \%$ glutaraldehyde) for particulate organic carbon (POC) analyses. After $12 \mathrm{~h}$, including one inundation period of $10 \mathrm{~h}$, one (seaward set) and two (landward set) sediment subcores (36- $\mathrm{mm}$ diameter, 200-mm length) were taken from the center of each imbedded sand core. These subcores were sliced immediately into $10-\mathrm{mm}$ (one set) and 5-mm (two sets) intervals, down to 100-mm depth. The subcore segments were brought to the laboratory in a cooler, and algal cells were extracted within $2 \mathrm{~h}$ after retrieval following the same procedure as described for FLUR. All intact fluorescent algal cells were counted.

The second field experiment (FLD-2) was carried out in Königshafen $\left(55^{\circ} 02^{\prime} \mathrm{N}, 8^{\circ} 26^{\prime} \mathrm{E}\right)$, an intertidal bay of Sylt island with a mean tidal range of $1.7 \mathrm{~m}$ (Reise 1985). Two artificial sand cores (grain sizes in Table 1) were inserted at low tide into the exposed sand flat sediment approximately 250-m offshore. In order to trace penetration of particulate matter into the experimental cores, fluorescent microbeads (3- $\mu \mathrm{m}$ diameter, density $1.05 \mathrm{~g} \mathrm{~cm}^{-3}$; Duke Scientific) suspended in particle-free North Sea water were poured on the sediment surface around the cores in a ring of approximately $25-\mathrm{mm}$ width and leaving $20-\mathrm{mm}$ distance from the outer edge of the core using a template. Tracer particle abundance in the rings was $(1.34 \pm 0.34) \times 10^{11} \mathrm{~m}^{-2}$. After one tidal inundation of $10 \mathrm{~h}$, two subcores (60-mm diameter, 200-mm length) were taken from each artificial core and sliced into $10-\mathrm{mm}$ sections down to 200-mm depth. Algae and beads were extracted from the segments and counted as described for FLU-R. Benthic and pelagic algae were counted separately, and here we report the results for the planktonic diatoms in the size range of 10 to $15 \mu \mathrm{m}$, which was the size range closest to that of Dunaliella. In field and chamber experiments, the maximum penetration depths of algae were defined as the depths where the exponential functions fitted to the Chl $a$ depth distributions reached $0.01 \mu \mathrm{g} \mathrm{cm}^{-3}$.

\section{Results}

Reference flume experiment ( FLU-S)_Advective pore water transport in the smooth sediment core was relatively small. Oxygen penetration into the core did not exceed 7-mm depth (Fig. 3), whereas diffusive oxygen penetration under stagnant water conditions reached to 3-5 $\mathrm{mm}$. However, the sediment subcores taken at the end of the experiment revealed that algal cells had penetrated into the sand. $72 \%$ of these cells were trapped in the upper $5 \mathrm{~mm}$, the rest were found between 5 and 10-mm depth (Fig. 4). Integrated over the whole depth of the subcores, we recorded $11.1 \pm 3.7 \mathrm{mg} \mathrm{Chl} a \mathrm{~m}^{-2}$, which corresponds to a flux of $3.7 \pm 1.2 \mathrm{mg} \mathrm{C} \mathrm{m}^{-2} \mathrm{~d}^{-1}$ (Table 2). 


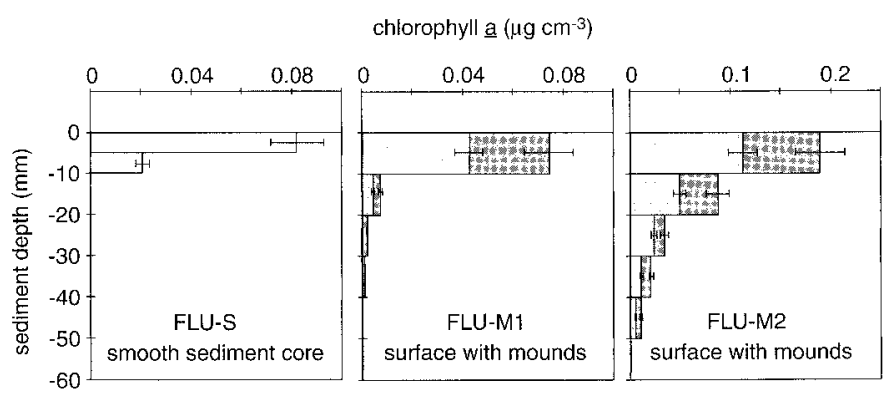

Fig. 4. Chlorophyll $a$ concentrations in the sediment cores with smooth surface and surface with mounds. Dark gray bars represent Chl $a$ in sediment subcores taken in the center of the intrusion areas, upstream of the mounds, light gray bars Chl $a$ in sediment subcores taken perpendicular to the mounds (compare Fig. 2).

Flume sediment cores with mounds (FLU-M1, FLUM2)-Oxygen penetrated 25-mm deep at the upstream edge of the mounds (FLU-M2, Fig. 3) revealing intrusion of oxygen-saturated flume water into the sediment core. With these interfacial flows, suspended algae were carried into subsurface sediment layers (Fig. 4). Consistent with the oxygen distribution, maximum penetration depths of Dunaliella were recorded at the upstream edge of the mounds; however, algae penetrated deeper than oxygen and cells were found down to 40 (FLU-M1) and $50 \mathrm{~mm}$ (FLU-M2). Owing to the interfacial transport, topography increased the trapping efficiency of the sediment. Advective infiltration of algae produced carbon fluxes exceeding that of the smooth reference FLU-S by factors of 2.1 (FLU-M1) and 1.7 (FLU-M2, Table 2).

Flume sediment core with ripple (FLU-R)_Upstream of the ripple, where water intrusion was strongest, algal cells were transported down to at least 70-mm depth (Fig. 5, the lower boundary of algal distribution was not reached by the subcores). The downstream penetration was less pronounced and restricted to the upper $50 \mathrm{~mm}$ of the core. In the center transect, maximum cell concentrations were recorded at 10mm depth, below the upstream slope of the ripple $(299 \pm$ $43 \times 10^{3}$ cells $\left.\mathrm{cm}^{-3}\right)$. Low numbers $\left(<6 \times 10^{3}\right.$ cells $\left.\mathrm{cm}^{-3}\right)$ were counted where pore water from deeper sediment layers was drawn to the surface. The side transect showed a similar distribution of algae, but due to the side wall effect in the flume (reduced flow speeds and pressure gradients), the advective transport of Dunaliella into the sediment was not as strong (maximum $219 \pm 25 \times 10^{3}$ cells $\mathrm{cm}^{-3}$ at 5 -mm depth) and reached less deep (Fig. 5). Integration of the cell numbers found in the center and side transect resulted in a flux of $33.5 \pm 26.2 \mathrm{mg} \mathrm{C} \mathrm{m}^{-2} \mathrm{~d}^{-1}$, the 9.1-fold of that recorded in the smooth control core.

Chamber experiments (CHA-1 and CHA-2)_Algal penetration depth increased with grain size (Fig. 6) and sediment permeability (Fig. 7). In CHA-1, algae reached 18-, 26-, 42-, and 56-mm depth in the 187-, 375-, 750-, and 1,500- $\mu \mathrm{m}$ sands, respectively. Because the natural sediments were less well sorted (Table 1), penetration depths in CHA-2 were lower (5, 12, 18, $26 \mathrm{~mm}$ for 105-, 150-, 600-, and 1,050$\mu \mathrm{m}$ sands). The coarser the sands, the more algae were transported into the sediment cores. The different filtration rates could be observed visually during the experiments (Fig. 8). At the end of CHA-1, the algal concentration in the water overlying the coarse sand had dropped to $4 \%$ of the initial concentration, whereas in the very fine sand the concentration had decreased to only $31 \%$ (Fig. 9, Table 3). The amount of Chl $a$ trapped by the sediment surface layer (upper $5 \mathrm{~mm}$ ) dropped with increasing grain size and accounted for 9 to $6 \%$ of the Chl $a$ decrease in the chamber water. Some sedimented algae accumulated in the calm zone in the center of the surface of the 187- and 375- $\mu \mathrm{m}$ sands (these algae were included in the final water column $\mathrm{Chl} a$ content); no such accumulations formed on the 750- and 1,500- $\mu \mathrm{m}$ sands. The total volume of Chl $a$ found below 5-mm sediment depth increased with permeability and accounted for $8 \%(187-\mu \mathrm{m}$ sand) to $13 \%(1,500-\mu \mathrm{m}$ sand) of the Chl $a$ decrease in the chamber water. The coarsest sand contained

Table 2. Organic carbon imported into the sediment calculated using the chlorophyll data recorded in the sediment cores and a chlorophyll to carbon ratio of 1:20 (Sims 1993; Verity et al. 1993). The normalized flux column lists the fluxes calculated assuming same average flume water carbon concentration in all experiments. For this normalization, we divided the average water carbon content measured in FLU-S by the average water carbon content of the respective experiment. For flux calculations in FLU-M1, which ran longer than the other flume experiments, we took the average water carbon content measured in the last $3 \mathrm{~d}$ of the experiment. The average carbon content in the sediment was calculated by integrating the carbon content of all subcores, and in the ripple experiment by integrating the areas of equal concentration (Fig. 5) and subsequent summation. The tracer-derived flushing rates were calculated from dye tracer experiments performed in similar sediment with similar topography (Huettel and Gust 1992; Huettel et al. 1996).

\begin{tabular}{|c|c|c|c|c|c|c|c|}
\hline & $\begin{array}{l}\text { Average in } \\
\text { water column } \\
(\mathrm{mg} \mathrm{C} \mathrm{L-1)}\end{array}$ & $\begin{array}{l}\text { Average in } \\
\text { sediment core } \\
\left(\mathrm{mg} C \mathrm{~m}^{-2}\right)\end{array}$ & $\begin{array}{l}\text { Normaliza- } \\
\text { tion } \\
\text { factor }\end{array}$ & $\begin{array}{c}\text { Normalized } \\
\text { flux } \\
\left(\mathrm{mg} \mathrm{C} \mathrm{m} \mathrm{m}^{-2} \mathrm{~d}^{-1}\right)\end{array}$ & $\begin{array}{l}\text { Increase } \\
\text { by factor }\end{array}$ & $\begin{array}{c}\text { Tracer } \\
\text { derived } \\
\text { flushing } \\
\text { rate } \\
\left(\mathrm{L} \mathrm{m}^{-2} \mathrm{~d}^{-1}\right)\end{array}$ & $\begin{array}{c}\text { Normalized } \\
\text { flux } \\
\text { calculated } \\
\text { using } \\
\text { flushing } \\
\text { rate } \\
\left(\mathrm{mg} \mathrm{C} \mathrm{m} \mathrm{m}^{-2} \mathrm{~d}^{-1}\right)\end{array}$ \\
\hline FLU-S & $0.8 \pm 0.7$ & $11.1 \pm 3.7$ & 1.0 & $3.7 \pm 1.2$ & 1.0 & 7 & 5.6 \\
\hline FLU-M1 & $0.5 \pm 0.3$ & $13.2 \pm 7.6$ & 1.7 & $7.6 \pm 4.4$ & 2.1 & 28 & 23.8 \\
\hline FLU-M2 & $2.4 \pm 1.1$ & $53.7 \pm 33.2$ & 0.4 & $6.3 \pm 3.9$ & 1.7 & 28 & 26.9 \\
\hline FLU-R & $1.0 \pm 0.8$ & $113.8 \pm 88.8$ & 0.9 & $33.5 \pm 26.2$ & 9.1 & 60 & 54.0 \\
\hline
\end{tabular}




\section{center transect (FLU-R)}

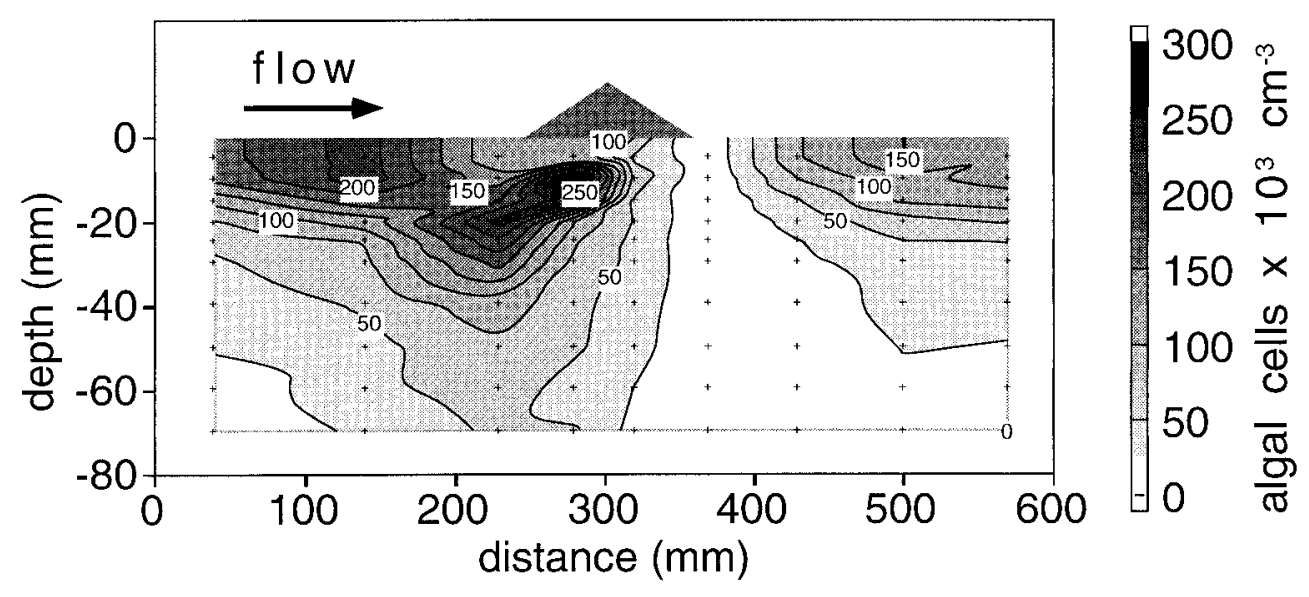

side transect (FLU-R)

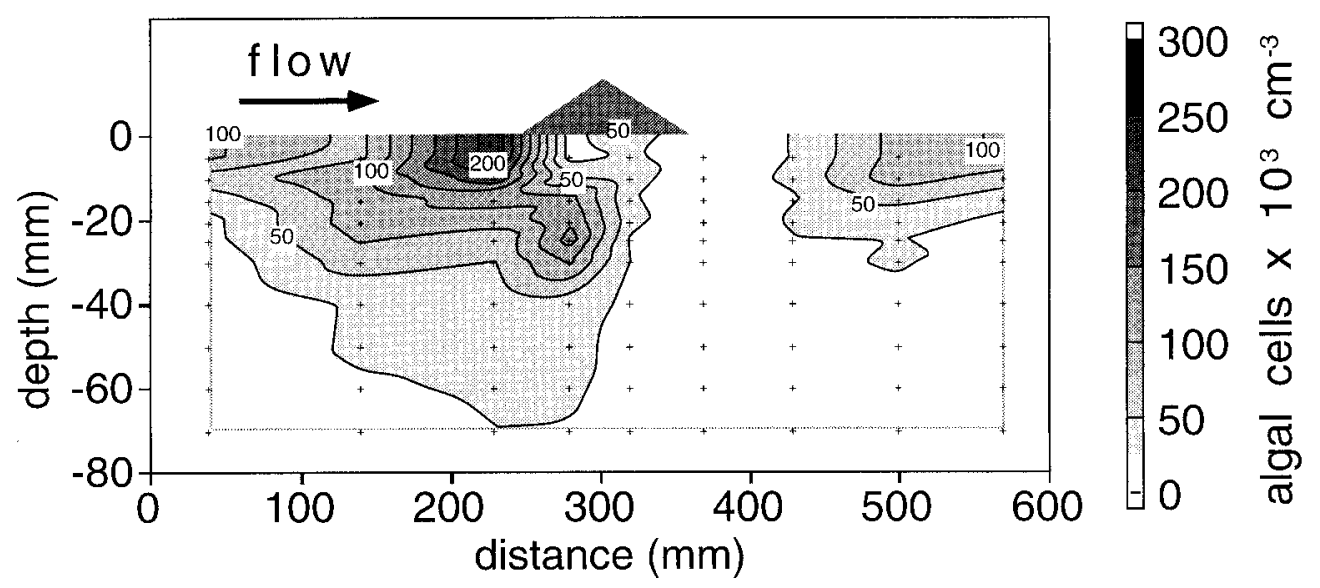

Fig. 5. Isoline diagrams generated from algal cell counts in subcores retrieved along center and side transect upon termination of the ripple experiment (FLU-R).

twice as many cells as the finest sand. CHA-2, with the natural sediments from the North Sea, confirmed the results of CHA-1 (Fig. 9, Table 3). Final concentrations of algae in the water overlying the coarse sand had decreased to $6 \%$ and in the muddy silt to $33 \%$ of the initial concentration. Sedimentary Chl $a$ reached maximum values in the coarsest sand. In contrast to CHA-1, the relative number of algae trapped by the surface proper increased with grain size.

The total number of phytoplankton cells that could be recovered from the chambers decreased with increasing permeability of the sediments (Fig. 9, Table 4). While 61 and $34 \%$ of the initially added cells could be regained from the chambers with impermeable bottom (CHA-1 - chamber with false bottom, CHA-2 - chamber with 105- $\mu \mathrm{m}$ sand), only $24 \%$ (CHA-1) and $17 \%$ (CHA-2) were found in the chambers with coarsest sands. Owing to the longer duration, the total number of cells recovered from the chambers in CHA2 was relatively lower than in CHA-1.
Field experiments (FLD-1, FLD-2)-At the time of experiment FLD-1, wave amplitudes were less than $20 \mathrm{~cm}$ and tidal currents at the study site reached maximum velocities of $18 \mathrm{~cm} \mathrm{~s}^{-1}$ at $10 \mathrm{~cm}$ above the sediment surface. Water samples taken at $5 \mathrm{~cm}$ above bottom had a POC content of $177 \pm 19 \mathrm{mg} \mathrm{C} \mathrm{dm}^{-3}$. Lateral sediment movement was negligible; at the end of the experiment, the surfaces of the embedded cores were not covered by surrounding sediment; however, small wave ripples had formed on the sands (amplitude $<15 \mathrm{~mm}$ ). During submergence, benthic and planktonic algal cells were transported into the embedded sand cores (Fig. 10). As found in the laboratory chamber experiments, penetration depth of algae grew linearly with the logarithm of sediment permeability (Fig. 7) and reached $12 \pm 10 \mathrm{~mm}$ (200- $\mu \mathrm{m}$ sand), $22 \pm 7 \mathrm{~mm}$ (500- $\mu \mathrm{m}$ sand), $29 \pm 3 \mathrm{~mm}(1,150-\mu \mathrm{m}$ sand $)$, and $38 \pm 10 \mathrm{~mm}(2,000-\mu \mathrm{m}$ sand). The total number of algae cells found in the sediments increased from $(20 \pm 15) \times 10^{3}$ cells cm$~_{-2}$ in the $200-\mu \mathrm{m}$ 


\section{sieved sands (CHA-1)}

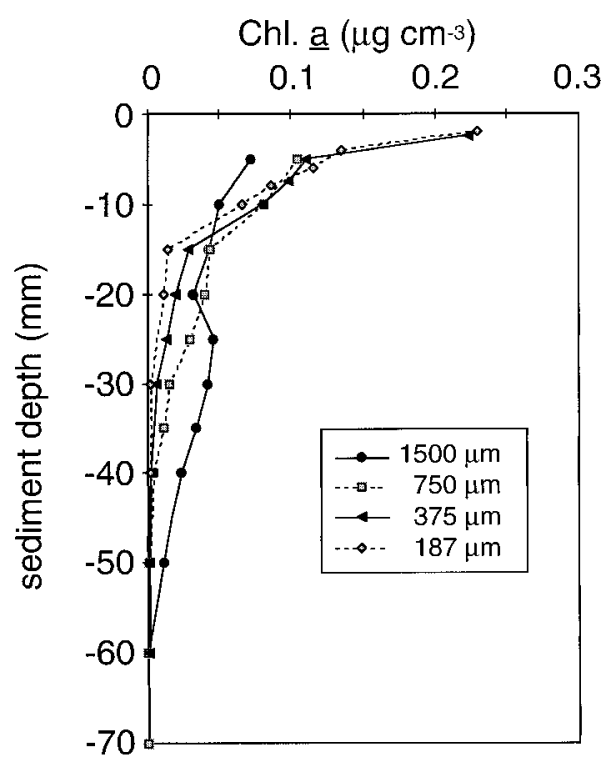

\section{natural sands (CHA-2)}

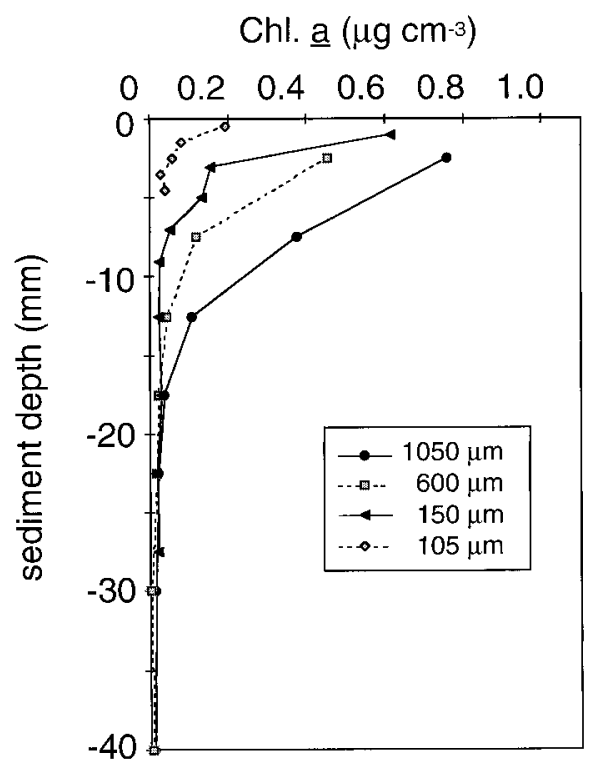

Fig. 6. Penetration depths of Dunaliella cells in the sediments incubated in the stirred chambers of experiments CHA-1 and CHA-2. Please note different depth scales.

sand to $(496 \pm 637) \times 10^{3}$ cells $\mathrm{cm}^{-2}$ in the $2,000-\mu \mathrm{m}$ sand (Table 5).

Weather and current conditions during FLD-2 were very similar to those in FLD-1; wave height was less than $20 \mathrm{~cm}$, bottom currents did not exceed $15 \mathrm{~cm} \mathrm{~s}^{-1}$, and sediment erosion was minimal. A water sample taken shortly after inundation contained $238 \times 10^{5}$ phytoplankton cells per liter. Penetration depths of phytoplankton cells of the 10- to 15 $\mu \mathrm{m}$ size class increased from $20 \pm 1 \mathrm{~mm}$ in the $187-\mu \mathrm{m}$ sand to $35 \pm 2 \mathrm{~mm}$ in the $750-\mu \mathrm{m}$ sand. The fluorescent

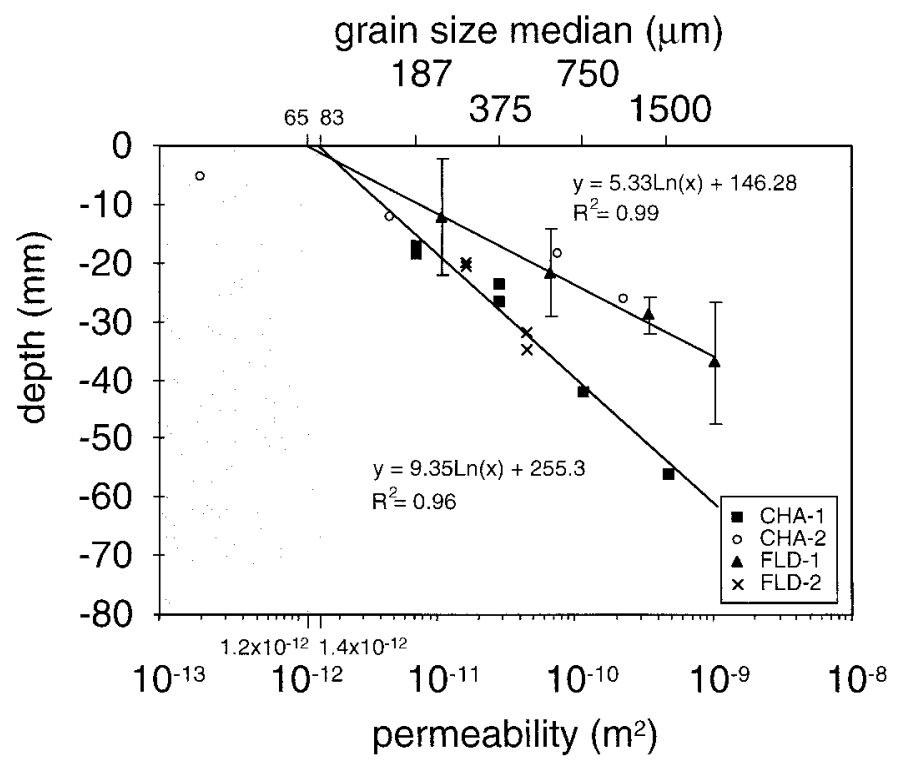

Fig. 7. Penetration depth vs. permeability for chamber and in situ experiments. No advective particle transport is possible in the gray zone. Grain size median values are given for comparison. tracer beads $(3 \mu \mathrm{m})$ were transported deeper, reaching $27 \pm$ $3 \mathrm{~mm}$ and $65 \pm 7 \mathrm{~mm}$ sediment depth in the 187- and 750$\mu \mathrm{m}$ sands, respectively. The $750-\mu \mathrm{m}$ sand contained 1.8 times as many algal cells as the $187-\mu \mathrm{m}$ sand (Table 5).

\section{Discussion}

Owing to their specific weight close to that of sea water, sedimented planktonic algae are resuspended by even the slightest boundary flow. In the shallow shelf, waves and strong bottom currents thus hinder the deposition of sinking phytoplankton. Frequent resuspension of the upper sediment layers periodically removes fine particles (Churchill et al. 1994; Grant et al. 1997) and exopolymeric substances from the sandy sea bed and impedes settling of benthic organisms, thereby maintaining high permeability and clean appearance of the sands. Our experiments demonstrate that in such an environment advective interfacial water flows provide a rapid and direct pathway for suspended phytoplankton cells into permeable sediment. With a particle Reynolds number of approximately $6 \times 10^{-5}$, path and velocity of the algal cells in our flume water were mainly controlled by the turbulent flow. The latter kept the algae in suspension, and visible accumulation of algal cells on the sediment surface did not occur. Contrasting this visual appearance of a nonaccumulating, clean sand bed, the analyses of the sediment revealed infiltration and deep penetration of algae into the sand when topography was present. The sand acted as an efficient particulate organic matter (POM) trap.

Interfacial transport-Two mechanisms were responsible for the transfer of algal cells into the sediment: interfacial water exchange caused by shear and water exchange driven by topography-related pressure gradients. The relatively high 

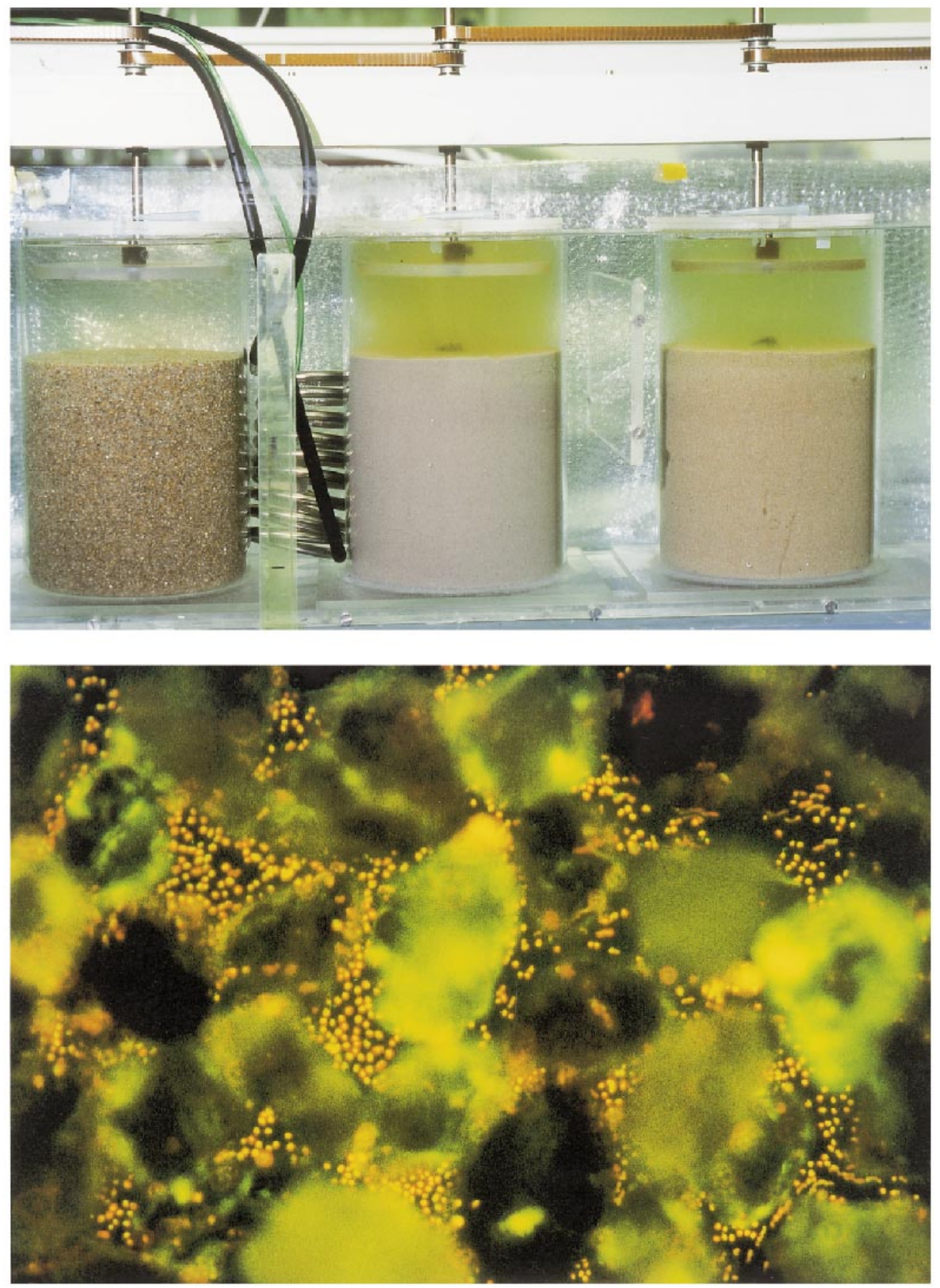

Fig. 8. The upper picture shows the chambers with 1,000-2,000- $\mu \mathrm{m}$ (left), 125-250- $\mu \mathrm{m}$ (middle), and 250-500- $\mu \mathrm{m}$ (right) sands on the last day of CHA-1. In the chamber with the coarsest sand, the Dunaliella cells had almost disappeared from the water column, whereas in the fine sand (middle chamber) most cells were still in the water and alive. The lower graph depicts Dunaliella cells in the interstices of $125-250-\mu \mathrm{m}$ sand, which demonstrates the space available for the algal transport with pore water flows.

permeability of the sediment permitted extension of the boundary layer velocity profile into the sand, with shear generating pore water flows in the upper $2-3 \mathrm{~mm}$ of the sand (Brinkman 1947; Beavers and Joseph 1967). Ensuing dispersion in this porous layer enhanced fluid exchange with the overlying water (Webster and Taylor 1992). The oxygen profiles measured in the smooth flume core (Fig. 3) were shaped by this exchange process; concentrations in the upper $2 \mathrm{~mm}$ of the sand did not decrease, but below that flushing depth they dropped sharply. This shear-driven interfacial wa- 

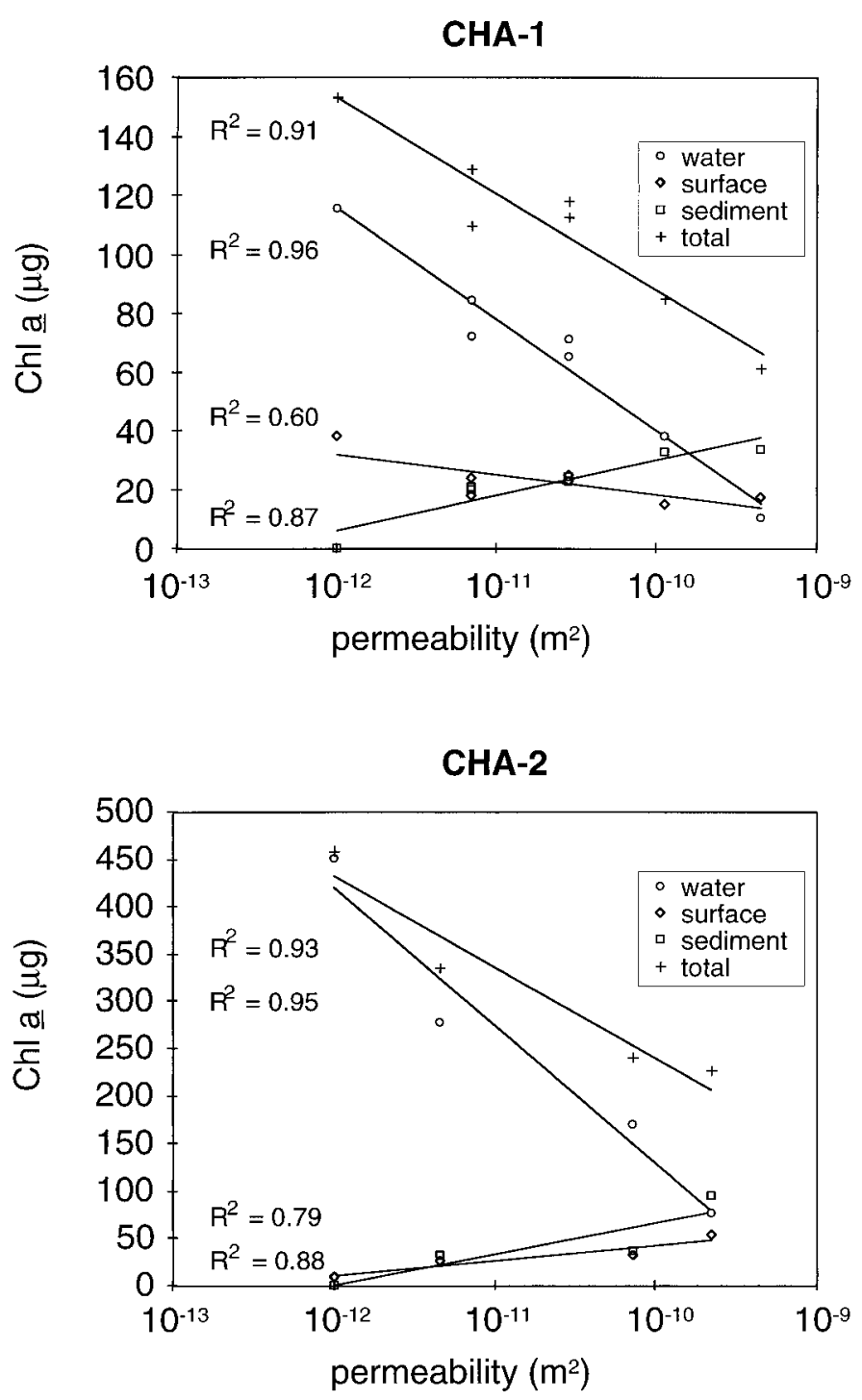

Fig. 9. Total chlorophyll and chlorophyll concentrations found in water, surface, and subsurface layers upon termination of CHA-1 and CHA-2.

ter exchange was responsible for the penetration of algae into the upper $5 \mathrm{~mm}$ of the sediment we found in the smooth control core (FLU-S, Fig. 4). Penetration of some algal cells below $5 \mathrm{~mm}$ in this core is attributed to surface heterogeneities. Huettel and Gust (1992a) showed that even surface roughness in the millimeter scale can enhance interfacial transport in permeable sands exposed to flow. Algae penetrated more than $70 \mathrm{~mm}$ into flume sediment with topography. In contrast to the shear-induced exchange that is dominated by surface-parallel pore water flows, the topography-related pressure areas force water at steep angles into the sand upstream and downstream of protruding surface structures (Fig. 1). The ensuing pore water flow field causes a distinct distribution of POM in the sediment with concentration maxima and minima (Fig. 5).

Limiting factors - Transport of suspended algae into and within the sediment is limited by the size of open pores in
Table 3. Carbon fluxes and sedimentary POC degradation rates (degradation $=$ cell loss) calculated for the chamber experiments and assuming $30 \mathrm{pg}$ C per Dunaliella cell (Sims 1993; Verity et al. 1993). Initial POC input in each chamber was $5 \mathrm{mg}$ in CHA-1 and $27 \mathrm{mg}$ in CHA-2. For CHA-1-sediments with same permeabilities the average values are listed.

\begin{tabular}{|c|c|c|c|c|c|}
\hline $\begin{array}{l}\text { Sediment } \\
\text { permeabil- } \\
\text { ity }\left(\mathrm{m}^{2}\right)\end{array}$ & $\begin{array}{c}\text { Final C } \\
\text { content } \\
\text { of water } \\
\text { and } \\
\text { surface } \\
(\mu \mathrm{g} \mathrm{C})\end{array}$ & $\begin{array}{l}\text { Differ- } \\
\text { ence to } \\
\text { "imperm- } \\
\text { eable", } \\
(\mu g \mathrm{C})\end{array}$ & $\begin{array}{c}\text { Flux } \\
\text { into } \\
\text { sedi- } \\
\text { ment } \\
\left(\mathrm{mg} \mathrm{C}^{-}\right. \\
\left.\mathrm{m}^{-2} \mathrm{~d}^{-1}\right)\end{array}$ & $\begin{array}{c}\text { Found in } \\
\text { sediment } \\
(\mu \mathrm{g} \mathrm{C})\end{array}$ & $\begin{array}{c}\text { POC } \\
\text { degra- } \\
\text { dation } \\
(\mathrm{mg} \mathrm{C} \\
\left.\mathrm{m}^{-2} \mathrm{~d}^{-1}\right)\end{array}$ \\
\hline \multicolumn{6}{|l|}{ CHA-1 } \\
\hline $4.6 \times 10^{-10}$ & 551 & 2,515 & 30 & 669 & 22 \\
\hline $1.1 \times 10^{-10}$ & 1,053 & 2,013 & 24 & 648 & 16 \\
\hline $2.8 \times 10^{-11}$ & 1,838 & 1,227 & 14 & 470 & 9 \\
\hline $7.1 \times 10^{-12}$ & 1,981 & 1,084 & 13 & 407 & 8 \\
\hline 0 & 3,066 & 0 & 0 & 0 & 0 \\
\hline \multicolumn{6}{|l|}{ CHA-2 } \\
\hline $2.2 \times 10^{-10}$ & 2,613 & 6,244 & 37 & 1,916 & 25 \\
\hline $7.3 \times 10^{-11}$ & 3,991 & 4,867 & 29 & 750 & 24 \\
\hline $4.6 \times 10^{-12}$ & 5,809 & 3,048 & 18 & 654 & 14 \\
\hline $2.3 \times 10^{-13}$ & 8,858 & 0 & 0 & 0 & 0 \\
\hline
\end{tabular}

the sand and the characteristics of the cells. Extrapolation of the recorded penetration depths sets the limit of advective algal transport to sand with a permeability of $1.4 \times 10^{-12}$ $\mathrm{m}^{2}$ and approximately $100-\mu \mathrm{m}$ grain size (Fig. 7). An increase of interfacial solute fluxes due to advective pore water flows can be measured when sediment permeabilities exceed $1 \times 10^{-12} \mathrm{~m}^{2}$ (Huettel and Gust 1992a; Huettel et al. 1998). Transport of algal cells into the sediment thus was found for almost the same permeabilities that facilitate detectable advective pore water flows, emphasizing the role of tight coupling between cell and water movement. In a well-sorted sediment with relatively spherical sand grains of $350-\mu \mathrm{m}$ diameter, like the one we used in the flume experiments, the pores have a diameter of about $30-50 \mu \mathrm{m}$. With an average diameter of $8 \pm 6 \mu \mathrm{m}$, the Dunaliella cells could easily be transported through these pores (compare relation to pore space in $125-250-\mu \mathrm{m}$ sands, Fig. 8). Penetration depth was determined by size, shape, density, surface characteristics of the algae, and, in case of living cells, their own movement. The spherical shape of Dunaliella, its elasticity and smooth, nonsticking cell surface reduced the friction between algae and sand grains. We found moving Dunaliella cells in the sediment samples, showing that living cells were transported into the sand. Motility facilitates advective transport of living cells within the sediment by increasing the fraction of time the cells spend in a detached versus an attached state (McCaulou et al. 1995). However, Dunaliella cells can move considerably faster (ca. $200 \mu \mathrm{m} \mathrm{s}^{-1}$, Schoevaert et al. 1988; Marano et al. 1989; Aleev 1991) than the maximum velocity of the advective pore water flows (ca. $100 \mu \mathrm{m} \mathrm{s}^{-1}$ in the uppermost $3 \mathrm{~mm}$ of the sediment core), and phototaxis and negative geotaxis should keep healthy cells from being carried into the sediment. Dunaliella cells transported into our sands may have been alive but probably were not fully mo- 
Table 4. Degradation (= cell loss) of algae in the different chambers. Calculations are based on the numbers of intact Dunaliella cells found in the chambers. The number of cells that was degraded in the chambers with "impermeable" bottom/sediment provided the maximum number of cells that were degraded in the water columns and surface. For CHA-1 sediments with same permeabilities, the average values are listed.

\begin{tabular}{lccccc}
\hline \hline & $\begin{array}{c}\text { Imperm- } \\
\text { eable } \\
\text { bottom }\end{array}$ & $\begin{array}{c}\text { Fine } \\
\text { sand }\end{array}$ & $\begin{array}{c}\text { Medium } \\
\text { sand }\end{array}$ & $\begin{array}{c}\text { Coarse } \\
\text { sand }\end{array}$ & $\begin{array}{c}\text { Very } \\
\text { coarse } \\
\text { sand }\end{array}$ \\
\hline Permeability $\left(\mathrm{m}^{2}\right)$ & 0 & $7.1 \mathrm{E}-12$ & $2.95 \mathrm{E}-11$ & $1.1 \mathrm{E}-10$ & $4.6 \mathrm{E}-10$ \\
Not degraded $(\%)$ & 61 & 48 & 46 & 34 & 24 \\
Maximum degraded in water $(\%)$ & 39 & 39 & 39 & 39 & 39 \\
Minimum degraded in sediment $(\%)$ & 0 & 13 & 15 & 27 & 37 \\
& Cohesive & Fine & Medium & Coarse & \\
CHA-2 & mud & sand & sand & sand & \\
Permeability $\left(\mathrm{m}^{2}\right)$ & $2.2 \mathrm{E}-13$ & $4.6 \mathrm{E}-12$ & $7.2 \mathrm{E}-11$ & $2.2 \mathrm{E}-10$ & \\
Not degraded $(\%)$ & 34 & 25 & 18 & 17 & \\
Maximum degraded in water $(\%)$ & 66 & 66 & 66 & 66 & \\
Minimum degraded in sediment $(\%)$ & 0 & 9 & 16 & 17 & \\
\hline
\end{tabular}

tile any more. Less or nonmotile planktonic organisms should be affected more strongly by the interfacial transport.

Subsurface maximum-The velocity of the advective flows gradually decreases with sediment depth (Huettel et al. 1996) and limits the penetration of algae to the depth where pore water moves too slowly to overcome the friction retarding the cells in the interstitial space. Algae can accumulate in that layer (Fig. 11). This process is responsible for the subsurface maxima we recorded in the flume experiment at the upstream edge of the ripple, where water intrusion was strongest (Fig. 5). In our relatively short chamber experiments, algal subsurface accumulation could only be observed in the coarsest sediment, where pore water flows were sufficiently strong to carry enough cells into the sand to produce a measurable maximum (Fig. 6, CHA-1, 1,500 $\mu \mathrm{m}$ ). In the second field experiment, concentration profiles of algae and tracer beads showed a subsurface maximum in the 750- $\mu \mathrm{m}$ sand at 30- to 40-mm depth (Fig. 10). Ripples that form on sandy shelf sediments due to bottom currents slowly move with or against the current direction. Because the pore water upwelling associated with ripples is too weak to effi-

\section{FLD-1}
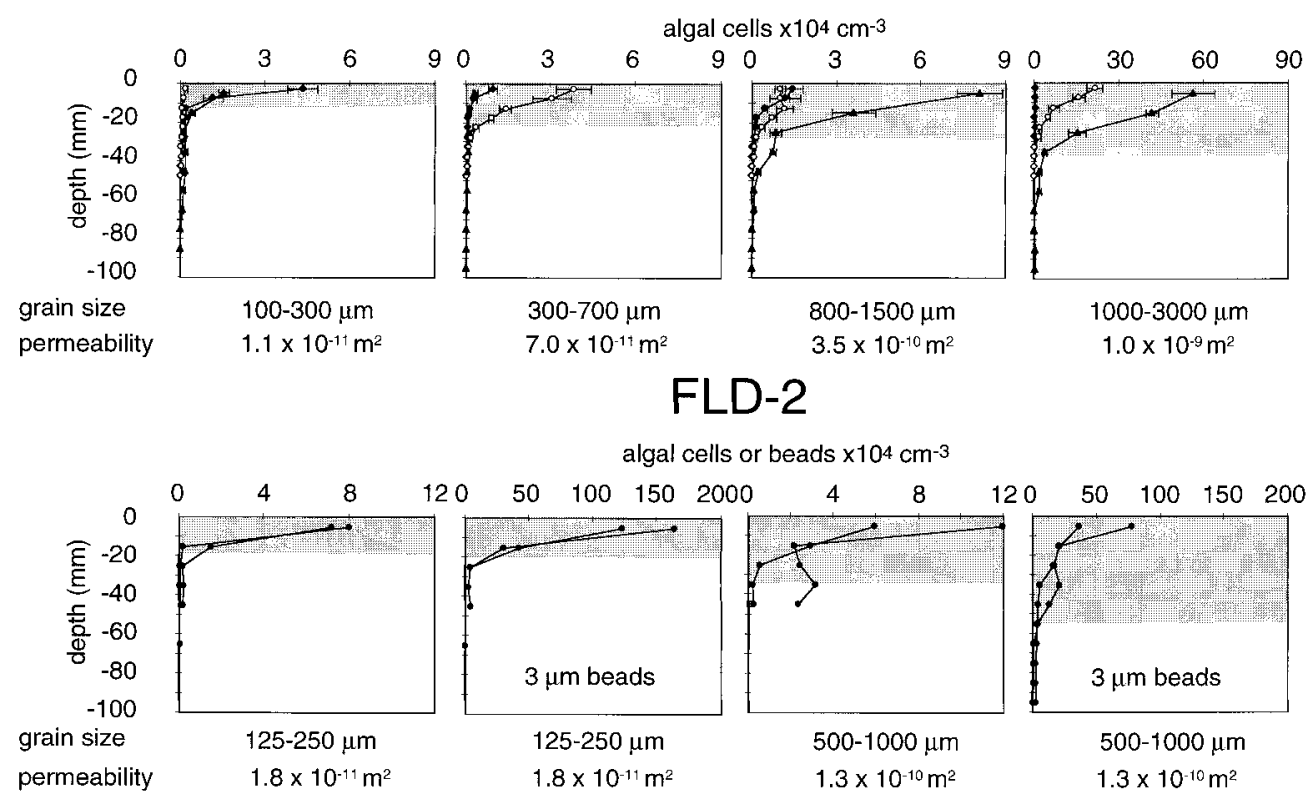

Fig. 10. Penetration of algal cells in the sediment cores inserted in intertidal sand flat sediment. In FLD-1, we lost the pore water of one of the subcores taken in the coarsest sediment due to a leak, causing almost a complete loss of infiltrated algae. Gray areas depict the maximum penetration depths of algal cells and microbeads, respectively. 
Table 5. The number of algal cells found in the sediment cores embedded in the intertidal sand flats. In FLD-1, all algal cells were counted. The counts listed for FLD-2 include only the planktonic diatoms in the size class $10-15 \mu \mathrm{m}$. Carbon fluxes were calculated assuming an average $\mathrm{C}$ content of $30 \mathrm{pg}$ per cell.

\begin{tabular}{|c|c|c|c|c|}
\hline & $\begin{array}{l}\text { Permea- } \\
\text { bility } \\
\left(\mathrm{m}^{2}\right)\end{array}$ & $\begin{array}{c}\text { Algae per } \\
\text { area } \\
\left(\times 10^{3}\right. \\
\left.\text { cells } \mathrm{cm}^{-2}\right)\end{array}$ & $\begin{array}{c}\text { Flux } \\
(\mathrm{mg} \mathrm{C} \\
\left.\mathrm{m}^{-2} \mathrm{~d}^{-1}\right)\end{array}$ & Factor \\
\hline FLD-1 & $\begin{array}{l}1.0 \mathrm{E}-09 \\
3.5 \mathrm{E}-10 \\
6.7 \mathrm{E}-11 \\
1.1 \mathrm{E}-11\end{array}$ & $\begin{array}{c}496 \pm 637 \\
58 \pm 68 \\
21 \pm 24 \\
20 \pm 15\end{array}$ & $\begin{array}{c}297 \pm 382 \\
35 \pm 41 \\
13 \pm 14 \\
12 \pm 9\end{array}$ & $\begin{array}{r}24.7 \\
2.9 \\
1.0 \\
1.0\end{array}$ \\
\hline FLD-2 & $\begin{array}{l}1.3 \mathrm{E}-10 \\
1.8 \mathrm{E}-11\end{array}$ & $\begin{array}{c}159 \pm 86 \\
89 \pm 6\end{array}$ & $\begin{array}{l}95 \pm 52 \\
54 \pm 4\end{array}$ & $\begin{array}{l}1.8 \\
1.0\end{array}$ \\
\hline
\end{tabular}

ciently remove particles from the deeper sediment layers, moving ripples can produce a subsurface layer of organic matter. In sand cores collected from the shallow South Atlantic Shelf and in laboratory incubations of these sediments, Marinelli et al. (1998) regularly observed ammonium and silicate peaks at 20 - to $80-\mathrm{mm}$ sediment depth that indicate decomposition of subsurface accumulations of organic matter.
Field validation - The field experiments showed the same linear relationship between penetration depth of algae and the logarithm of sediment permeability as the laboratory results, which indicates that the same transport process was responsible for the interfacial particle flux (Fig. 7). Currents and waves caused negligible sediment mixing, as shown by the small penetration depth of algae into the $100-300-\mu \mathrm{m}$ sand that had the lowest erosion threshold of the tested sediments. As there were no benthic animals in the embedded sand cores, we conclude that the dominant process transporting algae into the sand cores was advective pore water flow generated by the interaction of the small ripples on the cores and the tidal water currents. This conclusion is supported by the strong variability between the concentration profiles in each core. Sediment mixing by waves or currents would have produced a uniform distribution of algae in the sediments, while pore water upwelling and downwelling associated with sediment topography results in a patchy distribution of the imported material.

Flux enhancement-Our experiments demonstrate that permeable sediments with topography are efficient POM traps. Mounds, similar in size and abundance to those built by the polychaete Arenicola marina in intertidal sand flats, can double the flux of suspended unicellular algae into per-
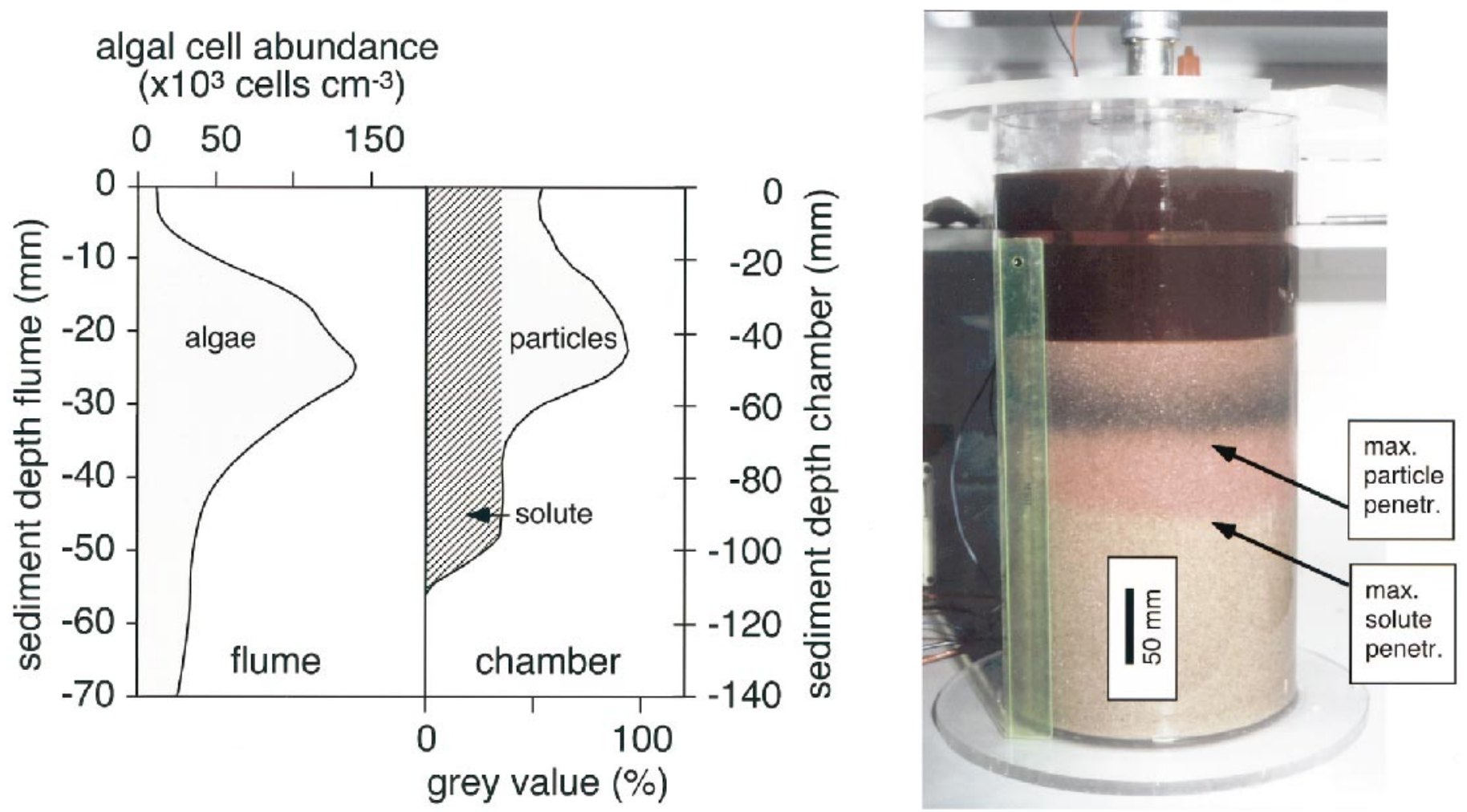

Fig. 11. Particle accumulation at a specific sediment depth demonstrated in a chamber experiment with solute (red) and particle (black) tracers, and in the flume ripple experiment (FLU-R) with algae. In the cylindrical chamber, the radial pressure gradient forced Rhodamine WT dye and black acrylic particles $(1 \mu \mathrm{m})$ into the sediment $(750 \mu \mathrm{m})$. Particles were transported downward until the pore water flow was too slow to overcome the friction between particles and sand grains. The particles accumulated in that layer, while the solute tracer was transported deeper into the core (right graph and photo). The same process caused the accumulation of algal cells in the flume sediment upstream of the ripple (left graph). 
meable sediment. The ripple had a stronger effect because it narrowed the free water flow more efficiently than the scattered mounds (Table 2). The real flux enhancements by mounds and ripple were even higher than the ones calculated from the concentrations of algae found in the flume sediments because these concentrations were reduced due to degradation of cells in the sands (Table 2). From experiments with inert tracers, we know the approximate volumes of water that are forced through the sediment at small mounds or ripples (Huettel and Gust 1992a; Huettel et al. 1996). Calculations using these flushing rates suggest that topography enhanced POC fluxes to the sediment up to factors of 5 (mounds) and 10 (ripple). The flux of algal cells into the sediments increased with permeability, and in the field experiments roughly doubled when permeability changed from $10^{-11} \mathrm{~m}^{2}$ to $10^{-10} \mathrm{~m}^{2}$ (Tables 3 and 5). A larger volume of water was forced through the coarser sands (Darcy 1856) transporting more algae into the sediment.

Recent investigations in sandy shelf beds support our experimental results. Bacon et al. (1994) reported that in permeable Atlantic Bight shelf sediments ( $>90 \%$ sand), where no net accumulation of sediment and organic matter presently occurs, the excess ${ }^{210} \mathrm{~Pb}$ inventories are nearly in balance with the atmospheric supply. Because ${ }^{210} \mathrm{~Pb}$ only enters the sediment adsorbed to particles, these findings imply that the sands efficiently retain fine particulate matter due to a trapping mechanism. Bacon et al. (1994) suggested that benthic organisms may be responsible for this particle uptake; we propose that advective filtration of bottom water through the upper layers of the sands contributed significantly to the particle trapping. Marinelli et al. (1998), in their recent investigations of nutrient profiles in South Atlantic Bight shelf sediments, found evidence that advective pore water exchange dominates interfacial solute fluxes over bioturbation in these sands. The time-averaged rate of mass transfer for nonlocal exchange in these permeable sediments exceeded that for diffusive exchange by as much as 50 -fold. As suspended particles are tightly linked to the interfacial water flow, these findings strongly suggest that in these South Atlantic Bight sediments, which have a median grain size up to twice as large as those used in our flume experiments, advective POM trapping is an important process.

Decomposition-With increasing permeability, the total number of algal cells that could be recovered from the chambers decreased. Penetration of algae into the sands accelerated the degradation process, cells disintegrated faster in the sediment than in the water column (in the following, when using "decomposition" or "degradation" in context with our experiments, we mean this disintegration of the algal cells and not complete mineralization). The contribution of phytoplankton degradation in subsurface layers of the sediments increased from $0 \%$ in the chambers with impermeable bottom to $37 \%$ (CHA-1) and $17 \%$ (CHA-2) in the chambers with the coarsest sands (Fig. 12). In the latter, more than twice as many algae were degraded within the same time period than in the chambers with impermeable bottom (Table 4). Increased mechanical stress, contact with bacteria-covered sand grain surfaces (Clement et al. 1997), and exposure to higher enzyme concentrations in the pore water could ex-

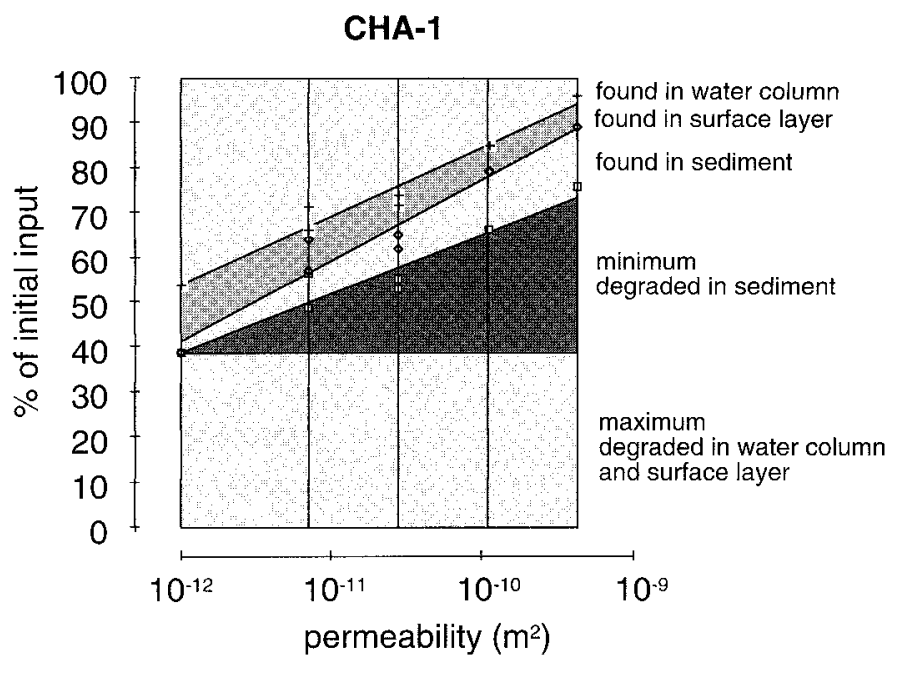

CHA-2

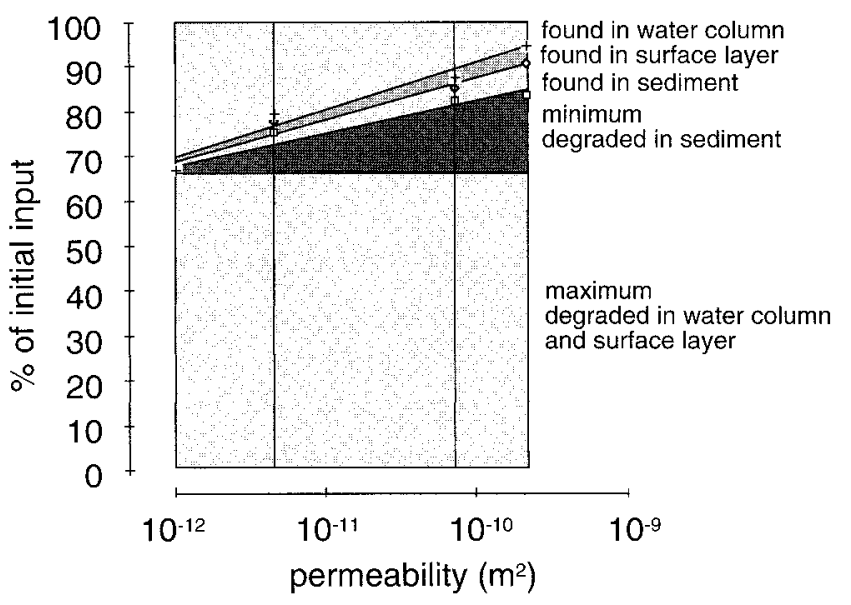

Fig. 12. Cumulative plots of the chamber results given in percentage of initial Dunaliella input. The number of algae that were degraded (disintegrated) within the sediment (dark triangular areas) is equal or larger than the difference between the total number of algae found in a chamber at the end of the experiment (upper part of plots) and the maximum number of algae that could have been degraded in the water column and sediment surface of that chamber (lower part of plots). The latter number was provided by the chambers with impermeable bottom, where degradation in sediment subsurface layers was excluded. Because filtration reduced the number of algae in the water of the chambers with permeable sediment, the number of cells degraded in these water columns probably was smaller and certainly not larger than in the chambers with impermeable bottom.

plain this result. Advective transport of oxygen into (Lohse et al. 1996; Ziebis et al. 1996) and decomposition products out of the sand (Gehlen et al. 1995; Huettel et al. 1998) further accelerate POM degradation. Oxygen consumption rates in nonaccumulating sands can be as high as in relatively impermeable accumulating muds (Andersen and Helder 1987; Marinelli et al. 1998). In the organic-poor sands at 12- to 30-m depth of the Middle Atlantic Bight, Reimers et al. (1996) measured oxygen consumption rates as high as 15 


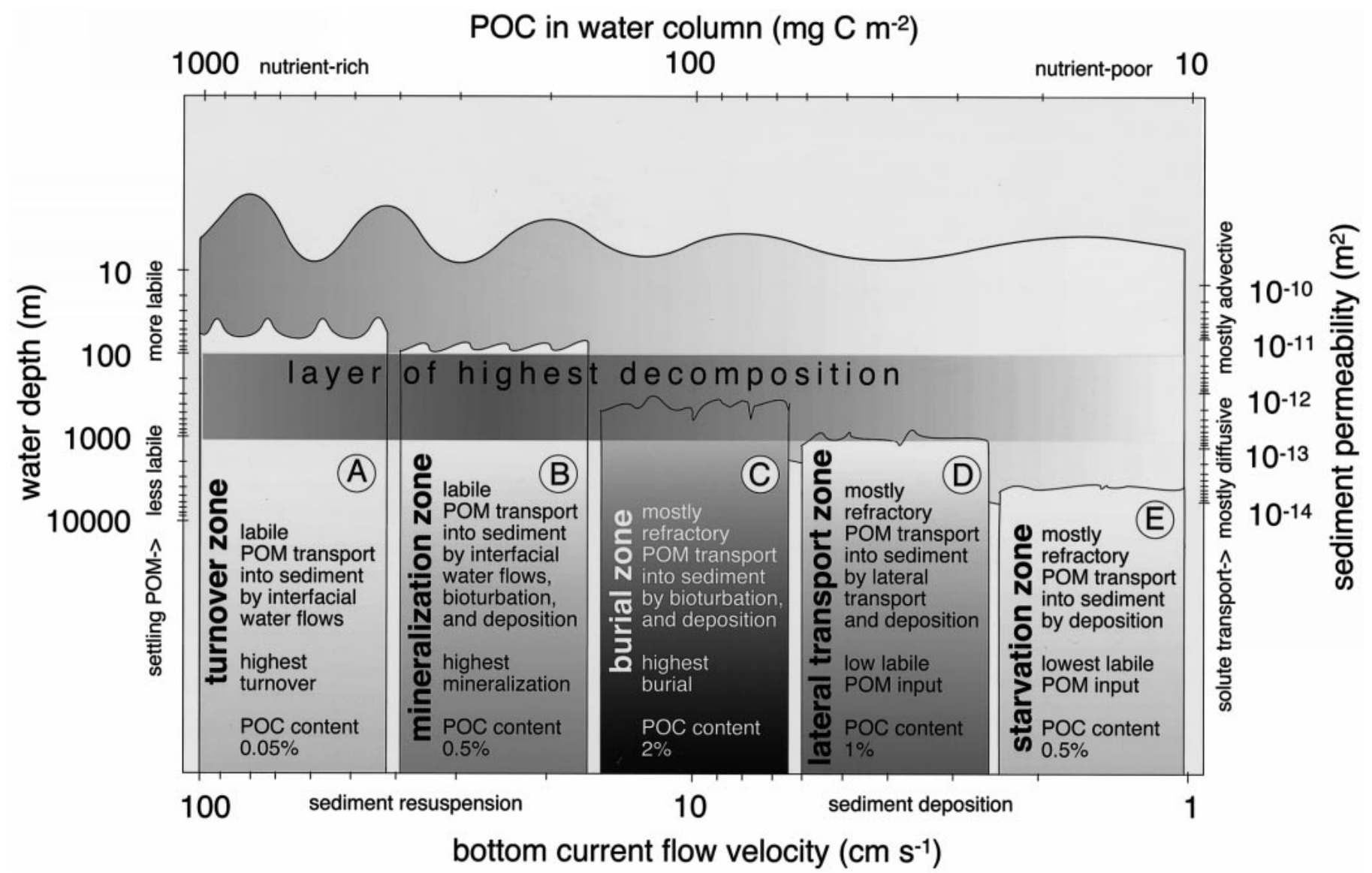

Fig. 13. A simplified scheme of the layer of accumulation and highest decomposition of sedimenting particulate organic matter demonstrating the increasing importance of sedimentary mineralization in the shelf. The layer of highest decomposition gradually moves into the sediment with decreasing water depth. (A) In the shallow shelf, wave and strong bottom currents cause frequent resuspension, which keeps the sediment highly permeable but also suppresses bioturbation due to mechanical stress. Labile POM mixed down from the highly productive photic zone is transported deep into the sands by strong advective pore water flows. Burial of organic matter is nil due to rapid turnover promoted by the interfacial flows of oxygen-saturated water. (B) Total sedimentary mineralization peaks between the shallow nonaccumulating shelf with highest turnover rates and the depocenter in the deeper shelf slope with the highest burial rates. In this zone, sporadic resuspension keeps the sediment sufficiently permeable to permit limited advective transport, but the bottom currents are weaker and allow occasional settling of organic particles and an abundant macrofauna to grow. Hydrodynamical and biological filtering and mixing mechanisms combine, which results in maximum uptake and decomposition rates of labile POM in the sediment. (C) The depocenter in the upper shelf slope receives mainly refractory organic material, and the slow bottom currents permit deposition of fine particles causing low sediment permeability. Ensuing lack of advective oxidation and reduced bioturbation promote anaerobic decomposition and highest burial rates. (D) Below the depocenter, POM input and the relative importance of the sediment for mineralization gradually decreases. Downslope POM transport gains importance. (E) Bacterial growth on sinking particulate organic matter peaks at 500-m water depth, where studies of ${ }^{210} \mathrm{~Pb}$ reveal also the greatest break up of particles (Turley et al. 1995). Only 2-4\% of surface water primary production reaches the sea floor at 4,500-m depth in the North Atlantic (Turley and Mackie 1994), minimizing the contribution of the sediment for its mineralization. Sediment POC contents listed in the graph were reported by (A) Hathaway (1971); Marinelli et al. (1998), (B), (C) Anderson et al. (1994), (D) Anderson et al. (1994); Rhoads and Hecker (1994), and (E) Rowe et al. (1994). Vertical extent of waves, sediment topography, and layer of highest decomposition not to scale. See text for further explanations.

mmol $\mathrm{m}^{-2} \mathrm{~d}^{-1}$. Low organic content of permeable sediments, thus, may be also a consequence of high turnover rates.

These findings may have significant implications for the cycling of organic matter in the shallow shelf. The closer the sediments are to the euphotic zone, the more important they become for the mineralization of sedimenting primary production because more labile material can reach the sea floor (Wollast 1991; Buscail et al. 1995; Olesen and Lundsgaard 1995). Moreover, total primary production increases up to an order of magnitude toward the coast due to nutrient input from land, atmosphere, and coastal upwelling (Rowe et al. 1975; Galloway et al. 1996; Jickells 1998; Seitzinger and Kroeze 1998). Despite highest concentration of POM in the water column, sedimentary POC and nutrient concentrations in large areas of the shallow shelf are very low (Bacon et al. 1994; Marinelli et al. 1998). The increasing hydrodynamic forces acting on the sea bed with decreasing water depth result in a coarsening of the sediment toward the shore, culminating in highly permeable beach gravel. The smaller specific surface area of the coarser sediments may 
explain a lower organic matter content (Hargrave 1972). However, the intensity of advective flushing of bottom water through the coarsening sediments increases toward the coast, and at less than 100-m depth is additionally enhanced by gravity wave induced pore water exchange (Riedl et al. 1972; Harrison et al. 1983; Malan and McLachlan 1991; Shum and Sundby 1996). Our experiments demonstrate that these interfacial flows filter suspended POM from the water column; permeable shelf sands thus represent gigantic filter systems. How efficient these filters are is revealed by the excess ${ }^{210} \mathrm{~Pb}$ inventories in sandy shelf sediments measured by Bacon et al. (1994). The distributions of ${ }^{210} \mathrm{~Pb}$ in suspended particulate matter and in the fine fraction of the Atlantic Bight shelf sediments indicate that the particles undergo several cycles of deposition/short-term burial/ resuspension that cause a far longer residence time in the shelf than predicted from the flushing time of shelf waters. We show that cycling of the POM through the sands accelerates the decomposition of this organic matter. With efficient particle trapping, acceleration of degradation, and fast nutrient release, the nonaccumulating permeable sediments become important sites of POM decomposition, tightening the cycling of matter in the shelf (Fig. 13). This could explain why organic production on the Middle Atlantic Bight shelf, where nonaccumulating sandy sediments dominate, is balanced primarily by consumption on the shelf, and only 2 to $20 \%$ of the primary production is exported (Rowe et al. 1986; Walsh 1988; Bacon et al. 1994).

Conclusion-In conclusion, we propose that permeable shelf sands are efficient POM filters and act as biocatalysts, accelerating mineralization of organic carbon and recycling of nutrients. High flushing rates, preventing the buildup of nutrients and refractory POM in the pore space, maintain their oligotrophic and nonaccumulating character. Benthic primary production, however, which produces up to 6 times more Chl $a$ in the surface $5 \mathrm{~mm}$ of the South Atlantic Bight shelf sands than the entire overlying water column (Nelson et al. 1999), indicates intensive sedimentary mineralization with high nutrient release from these beds. Nonaccumulating sandy sediments that cover extensive areas of all continental margins thus may play an important role in the cycling of matter in the shelf.

\section{References}

AleEv, M. Y. 1991. A new method for determining the swimming velocity of plankton organisms. Gidrobiol. Zh. 27: 70-74.

Aller, R. C. 1978. The effects of animal-sediment interactions on geochemical processes near the sediment-water interface, $p$. 157-172. In M. L. Wiley [ed.], Estuarine interaction. Academic.

Andersen, F., And W. Helder. 1987. Comparison of oxygen microgradients, oxygen flux rates and electron transport system activity in coastal marine sediments. Mar. Ecol. Prog. Ser. 37: 59-264.

Anderson, R. F., G. T. Rowe, P. F. Kemp, S. Trumbore, and P. E. BISCAYE. 1994. Carbon budget for the mid-slope depocenter of the Middle Atlantic Bight. Deep-Sea Res. II 41: 669-703.

Bacon, M. P., R. A. Belastock, AND M. H. Bothner. 1994. ${ }^{210} \mathrm{~Pb}$ balance and implications for particle transport on the continen- tal shelf, U.S. Middle Atlantic Bight. Deep-Sea Res. II 41: 511-535.

Basu, A. J., AND A. Khalili. 1999. Computation of flow through a fluid-sediment interface in a benthic chamber. Phys. Fluids 11: $1395-1405$.

BEAVERS, G. J., AND D. D. JosePH. 1967. Boundary conditions at a naturally permeable wall. J. Fluid Mech. 30: 197-207.

BRINKMAN, H. C. 1947. On the permeability of media consisting of closely packed porous particles. Appl. Sci. Res. A1: 81-86.

Burford, M. A., B. G. Long, And P. C. Rothlisberg. 1994. Sedimentary pigments and organic carbon in relation to microalgal and benthic faunal abundance in the Gulf of Carpentaria. Mar. Ecol. Prog. Ser. 103: 111-117.

Buscail, R., R. Pocklington, and C. Germain. 1995. Seasonal variability of the organic matter in a sedimentary coastal environment: Sources, degradation and accumulation (continental shelf of the Gulf of Lions, northwestern Mediterranean Sea). Cont. Shelf Res. 15: 843-869.

Churchill, J. H., C. D. Wirick, C. N. FlagG, and L. J. PietraFESA. 1994. Sediment resuspension over the continental shelf east of the Delmarva Peninsula. Deep-Sea Res. II 41: 341363.

Clement, T. P., B. M. Peyton, R. S. Skeen, D. A. Jennings, And J. N. Petersen. 1997. Microbial growth and transport in porous media under denitrification conditions: Experiments and simulations. J. Contaminant Hydrol. 24: 269-285.

DARCY, H. 1856. Les fontaines publiques de la ville de dijon. Dalmont.

EISMA, D., AND J. KALF. 1987. Distribution, organic content and particle size of suspended matter in the North Sea. Neth. J. Sea Res. 21: 265-285.

EMERSON, C. W. 1990. Influence of sediment disturbance and water flow on the growth of the soft-shell clam Mya Arenaria L. Can. J. Fish. Aquat. Sci. 47: 1655-1663.

EMERY, K. O. 1968. Relict sediments on continental shelves of the world. Am. Assoc. Pet. Geol. Bull. 52: 445-464.

Galloway, J. N., R. W. Howarth, A. F. Michaels, S. W. Nixon, J. M. Prospero, and F. J. Dentener. 1996. Nitrogen and phosphorus budgets of the North Atlantic Ocean and its watershed. Biogeochemistry 35: 3-25.

Gehlen, M., H. Malschaert, and W. R. VanRaAphorst. 1995. Spatial and temporal variability of benthic silica fluxes in the southeastern North Sea. Cont. Shelf Res. 15: 1675-1696.

Glud, R. N., S. Forster, AND M. Huettel. 1996. Influence of radial pressure gradients on solute exchange in stirred benthic chambers. Mar. Ecol. Prog. Ser. 141: 303-311.

, J. K. Gundersen, N. P. Revsbech, B. B. JøRGENSEN, AND M. Huettel. 1995. Calibration and performance of the stirred flux chamber from the benthic lander Elinor. Deep-Sea Res. I 42: $1029-1042$.

Graf, G. 1992. Benthic-pelagic coupling: A benthic view. Oceanogr. Mar. Biol. Ann. Rev. 30: 149-190.

Grant, J., P. Cranford, AND C. Emerson. 1997. Sediment resuspension rates, organic matter quality and food utilization by sea scallops (Placopecten Magellanicus) on Georges bank. J. Mar. Res. 55: 965-994.

HANSEN, L. S., AND T. H. BlaCKBURN. 1992. Effect of algal bloom deposition on sediment respiration and fluxes. Mar. Biol. 112: $147-152$

Hargrave, B. T. 1972. Aerobic decomposition of sediment and detritus as a function of particle surface area and organic content. Limnol. Oceanogr. 17: 583-596.

Harrison, W. D., D. Musgrave, and W. S. Reeburgh. 1983. A wave-induced transport process in marine sediments. J. Geophys. Res. 88: 7617-7622.

Hathaway, J. C. 1971. Data file, continental margin program, At- 
lantic coast of the United States, v. 2, Sample collection and analytical data. Woods Hole Oceanogr. Inst. 71-15: 489.

Huettel, M., AND G. Gust. 1992a. Impact of bioroughness on interfacial solute exchange in permeable sediments. Mar. Ecol. Prog. Ser. 89: 253-267.

, AND — 1992b. Solute release mechanisms from confined sediment cores in stirred benthic chambers and flume flows. Mar. Ecol. Prog. Ser. 82: 187-197.

- W. ZIEBIS, AND S. FORSTER. 1996. Flow-induced uptake of particulate matter in permeable sediments. Limnol. Oceanogr. 41: 309-322. AND G. W. LUTHER III. 1998. Advective transport affecting metal and nutrient distribution and interfacial fluxes in permeable sediments. Geochim. Cosmochim. Acta 62: 613-631.

JAGO, C. F., AND S. E. JonEs. 1998. Observation and modelling of the dynamics of benthic fluff resuspended from a sandy bed in the southern North Sea. Cont. Shelf Res. 18: 1255-1265.

Jenness, M. I., AND G. C. A. Duineveld. 1985. Effects of tidal currents on chlorophyll $a$ content of sandy sediments in the southern North Sea. Mar. Ecol. Prog. Ser. 21: 283-287.

JiCKELLS, T. D. 1998. Nutrient biogeochemistry of the coastal zone. Science 281: 217-222.

Jones, S. E., C. F. Jago, A. J. Bale, D. Chapman, R. J. M. HowLAND, AND J. JACKSON. 1998. Aggregation and resuspension of suspended particulate matter at a seasonally stratified site in the southern North Sea-physical and biological controls. Cont. Shelf Res. 18: 1283-1309.

Khalili, A., A. Basu, And M. Huettel. 1997. A non-Darcy model for recirculating flow through a fluid-sediment interface in a cylindrical container. Acta Mechanica 123: 75-87.

Lohse, L., E. H. G. EpPing, W. Helder, and W. Van RaAphorst. 1996. Oxygen pore water profiles in continental shelf sediments of the North Sea-turbulent versus molecular diffusion. Mar. Ecol. Prog. Ser. 145: 63-75.

Malan, D. E., AND A. MCLAChLAN. 1991. In situ benthic oxygen fluxes in a nearshore coastal marine system: A new approach to quantify the effect of wave action. Mar. Ecol. Prog. Ser. 73: $69-81$.

Marano, F., H. Berrebbah, D. Schovaert, C. Betrencourt, AND B. Volochine. 1989. Ciliary beat and cell motility of Dunaliella. Seventh International Congress Of Biorheology, p. 532.

Marinelli, R. L., R. A. Jahnke, D. B. Craven, J. R. Nelson, and J. E. ECKMAN. 1998. Sediment nutrient dynamics on the South Atlantic Bight continental shelf. Limnol. Oceanogr. 43: 13051320 .

McCaulou, D. R., R. C. Bales, and R. G. Arnold. 1995. Effect of temperature controlled motility on transport of bacteria and microspheres through saturated sediment. Water Resour. Res. 31: $271-280$

McLachlan, A. 1996. Physical factors in benthic ecology-effects of changing sand particle size on beach fauna. Mar. Ecol. Prog. Ser. 131: 205-217.

Milligan, T. G., AND P. S. HiLl. 1998. A laboratory assessment of the relative importance of turbulence, particle composition, and concentration in limiting maximal floc size and settling behaviour. J. Sea Res. 39: 227-241.

Nelson, J. R., J. E. Eckman, C. Y. Robertson, R. L. Marinelli, AND R. A. JAHNKE. 1999. Benthic microalgal biomass and irradiance at the sea floor on the continental shelf of the South Atlantic Bight: Spatial and temporal variability and storm effects. Cont. Shelf Res. 19: 477-505.

Olesen, M., AND C. LundsGaARD. 1995. Seasonal sedimentation of autochthonous material from the euphotic zone of a coastal system. Estuar. Coast. Shelf Sci. 41: 475-490.
ONG, B., AND S. KRISHNAN. 1995. Changes in the macrobenthos community of a sand flat after erosion. Estuar. Coast. Shelf Sci. 40: 21-33.

Pilditch, C. A., C. W. Emerson, and J. Grant. 1998. Effect of scallop shells and sediment grain size on phytoplankton flux to the bed. Cont. Shelf Res. 17: 1869-1885.

Reimers, C. E., S. M. GlenN, AND E. L. Creed. 1996. The dynamics of oxygen uptake by shelf sediments. EOS 76: 202.

REISE, K. 1985. Tidal flat ecology. Springer.

REVSBECH, N. P. 1989. An oxygen microsensor with guard cathode. Limnol. Oceanogr. 34: 474-478.

RHOADS, D. C. 1973. The influence of deposit-feeding benthos on water turbidity and nutrient recycling. Am. J. Sci. 273: 1-22. , AND B. HECKER. 1994. Processes on the continental slope off North Carolina with special reference to the Cape Hatteras region. Deep-Sea Res. II 41: 965-980.

RiEdL, R., N. HUANG, AND R. MACHAN. 1972. The subtidal pump: A mechanism of intertidal water exchange by wave action. Mar. Biol. 13: 210-221.

Riggs, S. R., S. W. Snyder, A. C. Hine, And D. L. Mearns. 1996. Hardbottom morphology and relationship to the geologic framework-Mid-Atlantic continental shelf. J. Sediment. Res. A 66: 830-846.

Rowan, K. S. 1989. Photosynthetic pigments of algae. Cambridge Univ. Press.

Rowe, G. T., G. S. Boland, W. C. Phoel, R. F. Anderson, and P. E. BISCAYE. 1994. Deep-sea floor respiration as an indication of lateral input of biogenic detritus from continental margins. Deep-Sea Res. II 41: 657-668.

, C. H. Clifford, K. L. Smith, JR., And P. L. Hamilton. 1975. Benthic nutrient regeneration and its coupling to primary productivity in coastal waters. Nature 255: 215-217.

$\longrightarrow$, S. Smith, P. Falkowski, T. Whitledge, R. Theroux, W. Phoel, AND H. DucKlow. 1986. Do continental shelves export organic matter? Nature 324: 559-561.

- AND OTHERS. 1988. Benthic carbon budgets for the continental shelf south of New England. Cont. Shelf Res. 8: 511527.

Savant, S. A., D. D. Reible, and L. J. Thibodeaux. 1987. Convective transport within stable river sediments. Water Resour. Res. 23: 1763-1768.

Schoevaert, D., S. Krishnaswamy, M. Couturier, And F. MarANO. 1988. Ciliary beat and cell motility of Dunaliella computer analysis of high speed microcinematography. Biol. Cell 62: 229-240.

Seitzinger, S. P., And C. Kroeze. 1998. Global distribution of nitrous oxide production and $\mathrm{N}$ inputs in freshwater and coastal ecosystems. Glob. Biogeochem. Cycles 12: 93-113.

Shum, K. T., AND B. SundBY. 1996. Organic matter processing in continental shelf sediments-The subtidal pump revisited. Mar. Chem. 53: 81-87.

SiMS, I. 1993. Measuring the growth of phytoplankton: The relationship between total organic carbon with three commonly used parameters of algal growth. Arch. Hydrobiol. 128: 459466.

Thibodeaux, L. J., and J. D. Boyle. 1987. Bedform-generated convective transport in bottom sediment. Nature 325: 341-343.

Turley, C. M., K. Lochte, And R. S. LampitT. 1995. Transformations of biogenic particles during sedimentation in the northeastern Atlantic. Philos. Trans. R. Soc. Lond. [Biol] 348: 179189.

, AND P. J. MACKIE. 1994. Biogeochemical significance of attached and free-living bacteria and the flux of particles in the NE Atlantic Ocean. Mar. Ecol. Prog. Ser. 115: 191-203.

Verity, P. G., D. K. Stoecker, M. E. Sieracki, P. H. Burkill, E. S. Edwards, AND C. R. Tronzo. 1993. Abundance, biomass 
and distribution of heterotrophic dinoflagellates during the North Atlantic spring bloom. Deep-Sea Res. II 40: 227-244.

WAlsh, J. J. 1988. On the nature of continental shelves. Academic. WebB, J. E., AND J. THEOdOR. 1968. Irrigation of submerged marine sands through wave action. Nature 220: 682-685.

Webster, I. T., AND J. H. TAYLOR. 1992. Rotational dispersion in porous media due to fluctuating flow. Water Resour. Res. 28: 109-119.

Wollast, R. 1991. The coastal organic carbon cycle: Fluxes, sourc- es, and sinks, p. 365-382. In M. J. M. Mantoura and R. F. C. Wollast [eds.], Ocean margin processes in global change. Wiley.

Ziebis, W., M. HuetTel, AND S. Forster. 1996. Impact of biogenic sediment topography on oxygen fluxes in permeable seabeds. Mar. Ecol. Prog. Ser. 140: 227-237.

Received: 9 August 1999 Amended: 6 December 1999 Accepted: 15 December 1999 